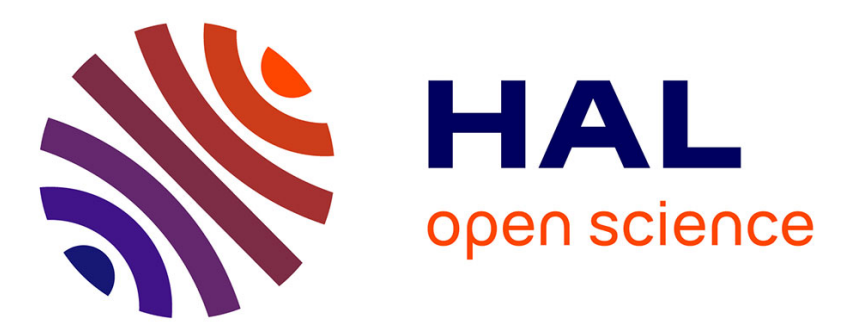

\title{
Neural effects of insecticides in the honey bee
}

\author{
Luc Belzunces, Sylvie Tchamitchian, Jean-Luc Brunet
}

\section{To cite this version:}

Luc Belzunces, Sylvie Tchamitchian, Jean-Luc Brunet. Neural effects of insecticides in the honey bee. Apidologie, 2012, 43 (3), pp.348-370. 10.1007/s13592-012-0134-0 . hal-01003656

\section{HAL Id: hal-01003656 https://hal.science/hal-01003656}

Submitted on 1 Jan 2012

HAL is a multi-disciplinary open access archive for the deposit and dissemination of scientific research documents, whether they are published or not. The documents may come from teaching and research institutions in France or abroad, or from public or private research centers.
L'archive ouverte pluridisciplinaire HAL, est destinée au dépôt et à la diffusion de documents scientifiques de niveau recherche, publiés ou non, émanant des établissements d'enseignement et de recherche français ou étrangers, des laboratoires publics ou privés.

$$
\text { Copyright }
$$




\title{
Neural effects of insecticides in the honey bee
}

\author{
Luc P. Belzunces, Sylvie Tchamitchian, Jean-Luc Brunet \\ INRA, UR 406 Abeilles \& Environnement, Laboratoire de Toxicologie Environnementale, Site Agroparc, \\ 84000 Avignon, France
}

Received 8 August 2011 - Revised 16 February 2012 - Accepted 6 March 2012

\begin{abstract}
During their foraging activity, honey bees are often exposed to direct and residual contacts with pesticides, especially insecticides, all substances specifically designed to kill, repel, attract or perturb the vital functions of insects. Insecticides may elicit lethal and sublethal effects of different natures that may affect various biological systems of the honey bee. The first step in the induction of toxicity by a chemical is the interaction between the toxic compound and its molecular target. The action on the molecular target can lead to the induction of observable or non-visible effects. The toxic substance may impair important processes involved in cognitive functions, behaviour or integrity of physiological functions. This review is focused on the neural effects of insecticides that have repercussions on (a) cognitive functions, including learning and memory, habituation, olfaction and gustation, navigation and orientation; (b) behaviour, including foraging and (c) physiological functions, including thermoregulation and muscle activity.
\end{abstract}

insecticides / neural effects / mode of action / molecular targets / behaviour

\section{INTRODUCTION}

The protection of crops against plant pests and pathogens is a particularly acute concern, not only in terms of economic impacts but also in terms of food resources, especially to fight hunger throughout the world. Phytopharmaceutical products, or pesticides, used for plant protection are composed mainly of xenobiotics, whose market comprises approximately $45 \%$ herbicides, $25 \%$ insecticides and $25 \%$ fungicides (UIPP 2011). In the insecticide family, neurotoxics are the main active substances used in numerous types of plant treatments including spraying, seed dressing, baits and granules.

Chemicals may elicit various effects in biological organisms through their interaction

Corresponding author: L.P. Belzunces, luc.belzunces@avignon.inra.fr Manuscript editor: Bernd Grünewald with numerous molecular targets that can induce lethal and adverse sublethal effects (Sattelle and Yamamoto 1988; Soderlund and Bloomquist 1989). This can be exemplified by the neurotoxic pyrethroid insecticides, which can trigger not only more of less severe neural effects but also reprotoxicity through a mechanism independent of their neural action (Yousef 2010; Zhang et al. 2010a, b; Joshi et al. 2011; Zhao et al. 2011). Thus, the intrinsic toxicity of insecticides may account for biological effects not always related to the mechanism of action that induces the expected effect, i.e. the insecticide action (Maeder et al. 2004). Regarding toxicodynamics, the starting point of the toxic effect of a substance lies in the interaction between the substance introduced in the organism and the molecular target. Thus, although all effects could be regarded as molecular, the molecular interaction between toxics and targets may result in "macroscopic" impacts that can be 
observed at cell, tissue, organ, individual and population levels, depending on their noxious action.

Insecticides are normally designed to reach insect pests, but they can also reach nonintentional organisms. Among the non-intentional organisms, the honey bee represents an insect of agro-environmental, economic and scientific importance (Gallai et al. 2009; Gauthier 2010; Srinivasan 2011). Insecticides may induce lethal and adverse sublethal effects in the honey bees either by direct contact during plant treatment, further residual contact with the treated plants or exposure to contaminated pollen and nectar. The sublethal effects can be observed at exposure levels below those eliciting the insecticide action. Consequently, the molecular targets triggering the sublethal effects generally have a higher affinity for the insecticides than the primary target responsible for the expected effect (Enan and Matsumura 1992).

This review is not an exhaustive survey of the literature. Its aim is to exemplify the complex action of insecticides at the neural level in the honey bee. The effects of insecticides are discussed more in terms of mechanisms of action than in terms of ecotoxicological impacts. Attention is focused on neurotoxic insecticides from the organophosphate, carbamate, pyrethroid, neonicotinoid and phenylpyrazole families. These pesticides present specific modes of action related to the insecticide activity (Table I) but can also share common molecular targets or targets not involved in the insecticide action.

\section{NEURAL EFFECTS OF INSECTICIDES}

The molecular interactions between insecticides and their biological targets may lead to effects impairing behaviour and physiology. Since all manifestations of the toxic substances have a molecular basis, the delineation of the nature of the effects induced by insecticides in honey bee depends on the prism through which the biologist observes the organisms. Thus, the clear distinction between behavioural and physiological effects might be questionable because behavioural effects resulting from an alteration of cognitive functions could also be regarded as physiological on the basis of the metabolic perturbations that induced them. Similarly, a distinction might be made between cognitive and non-cognitive behavioural impairments, especially for changes in behaviour due to functional alterations, e.g. disruption of muscular activity, spoliation of metabolic resources (Bounias et al. 1985). Here we chose to consider the impacts of insecticides on cognition, behaviour and physiological functions.

Table I. Specific modes of action related to the insecticide activity of pesticides.

\begin{tabular}{|c|c|c|c|c|}
\hline Insecticide class & $\begin{array}{l}\text { Main neuronal } \\
\text { target }\end{array}$ & $\begin{array}{l}\text { Mode of } \\
\text { Action }\end{array}$ & Effects & References \\
\hline Neonicotinoids & nAChR & Agonist & $\begin{array}{l}\text { Hyperactivation of } \\
\text { cholinergic neurones }\end{array}$ & $\begin{array}{l}\text { Tomizawa and } \\
\text { Casida (2005) }\end{array}$ \\
\hline Organophosphates & $\mathrm{AChE}$ & Inhibition & $\begin{array}{l}\text { Hyperactivation of } \\
\text { cholinergic neurones }\end{array}$ & Fukuto (1990) \\
\hline Carbamates & $\mathrm{AChE}$ & Inhibition & $\begin{array}{l}\text { Hyperactivation of } \\
\text { cholinergic neurones }\end{array}$ & Fukuto (1990) \\
\hline Pyrethroids & $\begin{array}{c}\text { Voltage-gated } \\
\mathrm{Na}^{+} \text {channel }\end{array}$ & $\begin{array}{l}\text { Prolonged } \\
\text { opening } \\
\text { of sodium } \\
\text { channels }\end{array}$ & $\begin{array}{l}\text { Increased sodium } \\
\text { permeability of } \\
\text { nerve membrane }\end{array}$ & $\begin{array}{l}\text { Soderlund and } \\
\text { Bloomquist (1989); } \\
\text { Soderlund et al. (2002); } \\
\text { Zhou et al. (2011) }\end{array}$ \\
\hline Phenylpyrazoles & $\begin{array}{l}\mathrm{GABA}_{\mathrm{A}} \mathrm{R} \\
\text { GluClR }\end{array}$ & $\begin{array}{l}\text { Antagonist } \\
\text { Antagonist }\end{array}$ & $\begin{array}{l}\text { Neuronal hyperactivation } \\
\text { Neuronal hyperactivation }\end{array}$ & $\begin{array}{l}\text { Ikeda et al. (2003); } \\
\text { Narahashi et } \\
\text { al. (2010) }\end{array}$ \\
\hline
\end{tabular}




\subsection{Cognition}

Cognition aggregates the neural processes involved in memory and the acquisition of knowledge, thought and awareness, perception, information treatment and interpretation, and problem solving. It may be regarded as a particularly attractive topic when considering the neural effects of insecticides. Cognition is involved in numerous types of behaviour and is fundamental to the social cohesion of the honey bee colony. It can be impaired by the direct interaction of chemicals with neural receptors, ionic channels and cell signalling pathways and also by modifications in the neural metabolism.

\subsubsection{Learning and memory}

Learning and memory processes are involved in the adaptation of the individuals to their environment and enable the bees to respond to the requirements of the colony throughout their life. The impacts of pesticide on memory have been investigated early through the study of the effect of ethyl-parathion, an organophosphate insecticide (OP), on time memory in bees trained to visit a feeding site (Schricker 1974). At a sublethal dose, parathion induced a shift of the visiting time to the early hours of the day. This shift can be explained either by a change in the circardian clock or by the adoption of new feeding schedules learned by associating time with food presence (Moore 2001; Bloch 2010). In a recent study, the effects on the learning and recall of visual and olfactory discrimination tasks have been studied in bees orally treated with the OP methyl-parathion (MP) (Guez et al. 2010). Since MP is recognised as a general acetylcholinesterase inhibitor, combined muscarinic and nicotinic cholinergic effects could be expected. Surprisingly, MP only enhances recall of the tasks learned with the visual and olfactory discriminants but has no effect on acquisition. Thus, the response elicited in the bees by MP has more of a muscarinic-like profile than a nicotinic profile (Gauthier et al. 1994, 2006; Cano Lozano et al. 1996; Cano Lozano and Gauthier 1998; Cano Lozano et al. 2001). This MP-elicited response has been interpreted in terms of an enhancement of cholinergic transmission, through acetylcholinesterase inhibition. However, OP are general inhibitors of serine hydrolases, e.g. esterases and amidases, some of which are involved in cell metabolism and intracellular signalling pathways (Petroianu et al. 2001; Galloway and Handy 2003; Adigun et al. 2010; Esquivel-Senties et al. 2010), and inhibition of neuropathy target esterases by OP, which triggers delayed neuropathies in mammals (Glynn 2005; Faiz et al. 2011; Jokanovic et al. 2011). In the honey bee, OP may have different targets involved in their toxicity. Pre-post and post-treatments of the bees by the oxime antidote 2-PAM (pralidoxime) completely protect acetylcholinesterase from in vivo inactivation by paraoxon but does not protect against mortality (Polyzou et al. 1998). Such a differential effect of 2-PAM strongly suggests that the action of OPs is not exclusively cholinergic and that there are secondary targets of great toxicological importance towards which 2-PAM is not effective (Chambers 1992).

Work on learning and memory was advanced by the introduction of the conditioning of the proboscis extension reflex (PER; Kuwabara 1957; Menzel et al. 1974; Bitterman et al. 1983). This paved the way to simplified laboratory procedures for investigating mnesic functions and discriminating the different phases of memory, namely encoding, including acquisition and consolidation, storage and retrieval (Gauthier 2010). This approach has been used for synthetic pyrethroids shortly after they became available on the market (Taylor et al. 1987; Mamood and Waller 1990). Bees subjected to a tarsal contact with sublethal doses of type I and type II pyrethroids exhibited an impairment of the conditioned response, which indicates that a residual contact with plants treated with pyrethroids may induce neural effects in bees at sublethal level. More recently, the effects of different pyrethroids on associative learning have been explored using a combination of semi-field and laboratory approaches (Decourtye et al. 2004b, 2005). In laboratory experiments, the bees have been continuously exposed for 11 days to a contaminated sucrose feeding solution 
containing different pyrethroids. Deltamethrin impairs the conditioned PER whereas $\lambda$ cyhalothrin, cypermethrin and $\tau$-fluvalinate seem not to affect behaviour although the levels of exposure to these substances are close. This demonstrates that effects induced by insecticides seem to be more substance-specific than familyspecific. In semi-field conditions, the presence of deltamethrin in food triggers a marked decrease in the number of foraging bees, which is reversed when the exposure ceases. This could be interpreted both in terms of repellent action of deltamethrin or in terms of health recovery after exposure since this deltamethrin treatment is considered to be lethal in this study.

During the past decade, the impacts of new insecticide families and biotechnological processes on cognitive functions have received special attention. Researches were conducted on the insecticide families, neonicotinoids and phenyl pyrazoles, developed in the mid-1990s (Schroeder and Flattum 1984; Johnston et al. 1986; Elbert et al. 1990; Klis et al. 1991a, b; Colliot et al. 1992; Sadler and Nieh 2011), and on the Bacillus thuringiensis toxins used in the development of genetically modified plants (GMP; Barton et al. 1987; Vaeck et al. 1987; Hofte and Whiteley 1989; Leemans et al. 1990; Tian et al. 1991; Jansens et al. 1992). The neonicotinoid family was first investigated in studies on its leading representative, imidacloprid, using various protocols based on olfactive conditioning. In both acute and subchronic exposure, imidacloprid triggers a decrease in learning performances, explored by looking at the conditioned PER (Decourtye et al. 2004a, b, 2005; Han et al. 2010). This effect depends on the season, and the bees are more sensitive to imidacloprid in the summer than in the winter (Decourtye et al. 2003). The PER approach has been complemented by semi-field experiments and an innovative T-tube maze assay (Decourtye et al. 2004b; Han et al. 2010). In semi-field conditions, the presence of imidacloprid in food triggers a marked decrease in the number of foraging bees, which is not reversed when the exposure ceases. The number of foraging bees is associated with a decay of olfactory performance and olfactory conditioning of PER. Complementary results obtained with acetamiprid and thiamethoxam point to the complex action of neonicotinoids, which strongly depends on exposure and is not always a characteristic of a given insecticide family. After acute exposure, acetamiprid, but not thiamethoxam, induces effects on associative learning and olfaction. Acetamiprid elicits an increase in sensitivity to antennal stimulation and impairs long-term retention of olfactory learning in oral exposure but not in contact exposure (El Hassani et al. 2008). Surprisingly, subchronic exposure to thiamethoxam, unlike acute exposure, leads to a decrease of olfactory memory and an impairment of learning performance but has no effect on memory (El Hassani et al. 2008; Aliouane et al. 2009). A new approach, based on bee behaviour in a T-tube maze, has been proposed to develop assays on associating learning that integrate visual and spatial orientation (Han et al. 2010). Bees that survive a subchronic treatment with imidacloprid present a reduced visual learning capacity in the T-tube maze procedure and decreased olfactory performances in the PER assay (Han et al. 2010).

The mechanisms by which neonicotinoids impair learning and memory performances may be more complex than expected. The metabolism of certain neonicotinoids in insects and plants results in the appearance of metabolites toxic to bees. In plants and in the honey bee, imidacloprid is transformed into different metabolites such as olefin and 5-hydroxyimidacloprid, which are toxic to the bees and are suspected to bind to the nicotinic acetylcholine receptor (Nauen et al. 2001; Suchail et al. 2001, 2004). The metabolism of thiamethoxam results in clothianidin, a metabolite as toxic as thiamethoxam that has been registered as insecticide (Nauen et al. 2003; Ford and Casida 2006; Benzidane et al. 2010). The toxicokinetics of acetamiprid in bees is somewhat different and leads to the appearance of 6chloronicotinic acid. This metabolite is toxic in chronic exposure but not in acute exposure and remains stable for at least $72 \mathrm{~h}$, especially in the head and the thorax (Suchail et al. 2001, 2004; 
Brunet et al. 2005). Thus, considering the toxicokinetics of imidacloprid, acetamiprid and thiamethoxam, it is very difficult to know what step of the memory process is affected by the parent compound or the metabolites: acquisition, consolidation or retrieval. At the environmental level, the metabolic profile of neonicotinoids in plants undergoes quantitative and qualitative changes during the flowering period (Laurent and Rathahao 2003). The differential exposure of bees to the parent compounds and metabolites over time changes the kinetics and the importance of the effects induced by the neonicotinoids and their metabolic derivatives.

Phenyls pyrazoles insecticides represent a family developed concomitantly to neonicotinoids in the mid-1990s. The first representative, fipronil, has often been investigated in insects and mammals (Caboni et al. 2003; Zhao et al. 2010; Sidiropoulou et al. 2011). In the honey bee, the effects of fipronil on learning and memory processes have been investigated using olfactory conditioning of the PER. Eleven days of subchronic exposure to fipronil induce a reduction in learning performances in the surviving bees (Decourtye et al. 2005; Aliouane et al. 2009). However, fipronil elicits differential effects consistent with several mechanisms of action. Injection of a low dose impairs the olfactory memory whereas a higher dose has no observable effect but can alter side-specific antennal tactile learning when applied to the thorax (Bernadou et al. 2009; El Hassani et al. 2009). The effect induced by the low dose is accentuated by the GABA analogue TACA, but can be rescued by the blocker of glutamate transport L-trans-PDC, this latter being able to reduce glutamate chloride currents in the antennal lobe cells. These results support the involvement of $\mathrm{GluCl}$ and $\mathrm{GABA}$ receptors in the impairment of olfactory memory triggered by fipronil. The $\mathrm{GluCl}$ ligand-gated chloride channel has been identified as a second target of fipronil that can induce an insecticidal action in numerous species (Ikeda et al. 2003; Zhao et al. 2003, 2004; Narahashi et al. 2010). This explains the sensitivity to fipronil of insect species resistant to cyclodienes, insecticides that also affect the GABA receptor (Scharf and Siegfried 1999; Zhao et al. 2005; Zhao and Salgado 2010). However, the fipronil-sulfone metabolite can also block the GABA- and Glutamate-activated chloride channels, and exposure to the parent compound may have delayed effects on memory processes (Zhao et al. 2005).

The use of B. thuringiensis strains for the biological control of numerous phytophagous insects has progressed remarkably during the past two decades. B. thuringiensis represents one of the most widely used bioinsecticides (James 2006) and can be used as bacterial, spore or crystal toxin suspensions against insect pests (Wei et al. 2003; Pigott and Ellar 2007; Sanahuja et al. 2011). The most recent development of $B$. thuringiensis involves the designing of plants genetically modified to synthetize $B$. thuringiensis toxins and to offer a quasipermanent shield against targeted pests. The GMP can express $B$. thuringiensis toxins in pollen and represent a potential hazard for bees if the transgene product is toxic, especially in the case of chronic exposure (Wraight et al. 2000; Li et al. 2010b). Exposure to B. thuringiensis toxins can also be observed after the degradation of maize detritus that leads to the occurrence of $B$. thuringiensis toxins within the stream networks of agricultural landscapes (Tank et al. 2010). However, B. thuringiensis toxins, originally used against insect pests, may also induce toxic effects in other organisms, such as man or nematodes, and may potentially affect bees (Wei et al. 2003; Ito et al. 2004). Experiments based on the olfactory conditioning of bees exposed subchronically to the $\mathrm{Cry} 1 \mathrm{Ab}$ toxin show that the learning performances, explored by the conditioned PER, are affected at a concentration of $5 \mathrm{mg} \mathrm{kg}^{-1}$. During the extinction phase, bees continue to respond to the conditioned odour even in the absence of a food reward. This effect is associated with an increase of the time the exposed bees need to consume the feeding syrup (Ramirez-Romero et al. 2008). No effect on learning performance is observed in free-flying bees exposed for 7 days 
to a syrup containing Cry $1 \mathrm{Ab}$ toxin at a concentration of $1 \mathrm{mg} \mathrm{kg}^{-1}$, but the toxin causes a lasting reduction in foraging activity during and after exposure (Ramirez-Romero et al. 2005). T-tube maze and PER have been used to study the effect of pollen from the transgenic Cry1Ac (BT toxin) + CpTI (Cowpea trypsin inhibitor) cotton cultivar CCRI41. No effect was observed (Han et al. 2010).

\subsubsection{Habituation}

Habituation may be defined as a form of learning that consists in the gradual and relatively prolonged decrease of the intensity or the frequency of a response following the repeated or prolonged stimulus responsible for eliciting such a response (Braun and Bicker 1992; Epstein et al. 2011). Thus, habituation leads to individuals that are tolerant to the triggering stimulus. It represents a particularly important process for the bees since it enables them to avoid both worthless responses to uninteresting stimuli and waste of time and energy.

The effect of pesticides on habituation is not well documented. One way to study habituation in the honey bee involves the PER elicited by an antennal contact with a sucrose solution. This is done by analysing the number of antennal contacts with a sucrose solution necessary to observe an arrest of proboscis extension. Neonicotinoid imidacloprid accelerated the PER habituation in honey bees topically treated with a sublethal dose (Lambin et al. 2001). The same approach, with antennal stimulations at shorter time intervals, has been used in 7- and 8-day-old bees. In these bees, averages of 7 and 14 trials are required to observe habituation, respectively (Guez et al. 2001). The 7- and 8-day-old bees were chosen because the bees initiated their short orientation flight at this age in this study. During the first hour, imidacloprid increases the number of trials needed to achieve habituation in 7-day-old bees but decreases it in 8-day-old bees. The habituation profile obtained with imidacloprid evolves with time, particularly in 8-day-old bees, for which the number of trials needed to achieve habituation increases $4 \mathrm{~h}$ after exposure to imidacloprid. The evolution of the habituation profiles with time is due to the action of imidacloprid metabolites olefin and 5-hydroxyimidacloprid that delay and accelerate habituation, respectively (Guez et al. 2003). These results suggest the existence of two nicotinic acetylcholine receptors (nAChR) differentially expressed during maturation of young bees. The existence of two imidacloprid binding sites has been demonstrated in aphids and in the brown planthopper Nilaparvata lugens. In aphids, it occurs two binding sites whose dissociation constants $\left(K_{\mathrm{d}}\right)$ are $0.14 \mathrm{nM}$ for the high affinity site and $12.6 \mathrm{nM}$ for the low affinity site. It should be noted that with a $K_{\mathrm{d}}$ of $12.6 \mathrm{nM}$, the "low affinity" site has a relatively high affinity for imidacloprid. However, since its pharmacology has not been studied, it is not sure that this site corresponds to a nAChR (Lind et al. 1998). In $N$. lugens, two binding sites of high $\left(K_{\mathrm{d}}=\right.$ $1.5 \pm 0.2 \mathrm{nM})$ and very high $\left(K_{\mathrm{d}}=3.5 \pm 0.6 \mathrm{pM}\right)$ affinity for imidacloprid corresponding to nAChRs have been identified (Li et al. 2010a). Immunodepletion experiments strongly suggest that nAChRs containing $\mathrm{Nl} \alpha 1, \mathrm{Nl} \alpha 2$ and $\mathrm{Nl} \beta 1$ subunits constitute the lower affinity binding site, whereas $\mathrm{nAChRs}$ containing $\mathrm{Nl} \alpha 3, \mathrm{Nl} \alpha 8$ and $\mathrm{Nl} \beta 1$ constitute the higher affinity binding site for imidacloprid. In bees, using a whole-cell voltage-clamp approach, it has been shown that imidacloprid acts as a nearly full agonist or as a partial agonist, depending on the neuron population (Nauen et al. 2001; Déglise et al. 2002). This suggests the existence of different $\mathrm{nAChR}$ subpopulations. There are major discrepancies between binding and electrophysiological studies (Nauen et al. 2001). As imidacloprid induces inward currents at micromolar concentration, $\left[{ }^{3} \mathrm{H}\right]$-imidacloprid can bind on membrane preparations at a subnanomolar concentration level. This clearly shows different binding sites with large differences in affinity exist in bees. However, the pharmacology of the $\left[{ }^{3} \mathrm{H}\right]$-imidacloprid binding activity and inward currents induced has not been performed, and the nature of the different receptors remains controversial. It is noteworthy that the concentration ratio 
observed between binding activity and inward current induction is in accordance with the ratio observed between effects induced in acute and chronic exposures (Suchail et al. 2001). However, the existence of several nAChR that are able to interact with imidacloprid and that exhibit different subunit compositions, locations and desensitisation kinetics shows the complexity of the effects induced by neonicotinoids in the honey bee (Thany et al. 2003; Thany and Gauthier 2005; Barbara et al. 2008; Gauthier 2010; Dupuis et al. 2011).

\subsubsection{Olfaction and gustation}

Olfaction and gustation represent important physiological senses that condition the life of the honey bee colony both at the individual and colony levels. They may not be considered as purely cognitive processes, but the behavioural and physiological responses they trigger are processed at the neural level. Both olfaction and gustation are involved in scent and taste detection and recognition required for the bee to associate flowers with nectar production, detect and visit or revisit a food source, recognise individuals foreign to the hive, recruit foragers, achieve chemical communication, ensure the social cohesion of the colony and, in some cases, detect plant allelochemicals (Detzel and Wink 1993; Giurfa 1993; Balderrama et al. 1996; Goulson et al. 2001; Reinhard et al. 2004; Gawleta et al. 2005; Couvillon et al. 2010; Maisonnasse et al. 2010; Kather et al. 2011).

Pesticides may influence the bee behaviour in relation to olfactory and gustatory senses either directly by inducing an attraction or deterrence, or indirectly by acting on physiological processes involved in scent recognition or in the neural treatment of gustatory and olfactive signals. The attraction of the bees by pesticides is not interesting from a toxicological point of view because it increases the probability of exposure to plant treatment products. Thus, early in research on honey bee toxicology, it was proposed the use of repellent additives to reduce pesticide hazard to honey bees (Atkins et al. 1975, 1977; Solomon and Hooker 1989).
Some pesticides may have an intrinsic deterrent effect, or repellency, that can reduce bee exposure following a treatment with agrochemicals. Organophosphates induce a rapid decrease in the number of foraging bees, a phenomenon that was first attributed to repellency (Barker et al. 1980; Shires et al. 1984a; Pande and Bandopadhyay 1985; Danka and Collison 1987). However, in laboratory and field tests, no repellency, via olfaction or after contact or ingestion, can be demonstrated, and a repellent action can only be observed at exaggerated dosages. In fact, the apparent organophosphate repellency is actually due to a fast loss of honey bee vitality accompanied by a fast decrease in foraging activity. This vitality loss resulted in an important delayed mortality due to substance exchanges, by trophallaxy and brushing. The mortality rate can reach $50-80 \%$ of the colony, even if the number of exposed bees is low. This toxicity profile appears as the hallmark of the organophosphate action in bees (Shires et al. 1984a, b).

The pyrethroid insecticides of the first generation were not photostable and were subjected to rapid UV-degradation in fields. The introduction of photostable pyrethroids in the late 1970s added interest to investigations on repellency as a tool for better management of adverse sides effects of insecticide plant treatments (Ueda et al. 1974; Ruzo et al. 1977; Ruzo et al. 1980; Takahashi et al. 1985). Pyrethroids demonstrate a repellent action in laboratory, cage and field studies (Bos and Masson 1983; Delabie et al. 1985; Rieth and Levin 1988, 1989). It is noteworthy that pyrethroid repellency does not protect the bees visiting the crop during the treatment. In the field, the foraging decrease connected to pyrethroids is not always associated with a very high mortality rate, as was the case for organophosphates. There is no discrepancy between exposure and effects, and the number of dead bees is correlated to the number of foragers present during crop treatments. The repellent action of pyrethroid has been estimated to last about $24 \mathrm{~h}$, not long enough to prevent bees from residual contact toxicity (Taylor et al. 1987; Mamood and Waller 
1990). However, pyrethroid insecticides and fungicides are frequently associated by farmers to reduce the number of treatments and thus to save time. The combination with certain fungicides reduces the repellency of $\alpha$-cypermethrin and $\lambda$-cyhalothrin with a particularly marked effect with chlorothalonil, tebuconazole and iprodione/thiophanate-methyl. This leads to an increase of exposure to the pesticides used in plant protection and the risk to the bees, especially with fungicides that act in synergy with pyrethroids such as azole fungicides (Colin and Belzunces 1992; Chalvet-Monfray et al. 1995, 1996a, b; Pilling et al. 1995; Thompson and Wilkins 2003). Furthermore, pyrethroids impair the functioning of antennal olfactory receptor neurons and can cancel their repellency in bees surviving sublethal doses (Kadala et al. 2011).

The effects of insecticides on gustation can be investigated by studying the modulation of the gustatory threshold, which can be defined as the lowest concentration of a sucrose solution applied to the antenna able to elicit a PER. The action of neonicotinoids on gustation seems somewhat complex. Bees treated topically with imidacloprid exhibit an increase of the gustatory threshold (Lambin et al. 2001). This effect is delayed and increases with time during $60 \mathrm{~min}$ and seems to involve an active metabolite. This contrasts with acetamiprid that increases the sensitivity to an antennal stimulation by sucrose in oral but not in contact exposure (El Hassani et al. 2008). For responsiveness to water, reciprocal results are obtained with an increase either in contact (El Hassani et al. 2008) or in oral exposure (Aliouane et al. 2009). Thiamethoxam induces either no effect on sensitivity to sucrose (El Hassani et al. 2008) or a decrease of sucrose stimulation observed only at high sucrose concentrations (Aliouane et al. 2009). Part of these results is conflicting with the action of nicotine that causes a rapid decrease of the sucrose threshold after injection in the antennal lobes (Thany and Gauthier 2005). However, imidacloprid also exhibits an antagonist action on neuromuscular nicotinic acetylcholine receptors. This clearly shows the existence of exceptions to the well-established agonist action of imidacloprid on insect neural acetylcholine receptors (Seifert and Stollberg 2005). Assuming that neonicotinoids act exclusively on nAChR, such a complex response could be interpreted only by a differential action of neonicotinoid parent and metabolite compounds on different molecular targets involved in the perception and treatment of the olfactory signal. Thus, nAChR occurring in antennal lobes, in $\alpha$-lobes and calyces of the mushroom bodies are good candidates for neonicotinoid sites of action (Goldberg et al. 1999; Armengaud et al. 2000; Cano Lozano et al. 2001; Déglise et al. 2002; Thany et al. 2003; Thany and Gauthier 2005; Barbara et al. 2008). However, nAChR of the Kenyon cells (a subset of olfactory interneurons) exhibit complex pharmacology and respond to muscarinic and non-cholinergic antagonists (Wüstenberg and Grünewald 2004). Therefore, the sensory response of neonicotinoids may change according to the chemical structure of parent and metabolite compounds, at least in this cell type.

The phenyl pyrazole fipronil elicits a decrease of sensitivity to sucrose after contact application but not through oral application (El Hassani et al. 2005). This effect appears $1 \mathrm{~h}$ after the treatment and strongly suggests an action mediated by a metabolite and particularly the sulfone derivative, a metabolite blocking both GABA and Glutamate chloride channels like fipronil (Zhao et al. 2005; Li and Akk 2008). The fipronil action could easily be ascribed to an interaction of the parent compound or a metabolite with GABA or GluCl ionic channels (Murillo et al. 2011; Wolstenholme et al. 2000; Caboni et al. 2003; Ikeda et al. 2003; Zhao et al. 2003; Narahashi et al. 2010). However, the GABAergic antagonists bicuculline and picrotoxine partially block the acetylcholine-induced current in Kenyon cells, preferentially affecting the fast transient component of the nicotinic current (Wüstenberg and Grünewald 2004). Thus, it is not possible to fully ascertain that the action of fipronil is only restricted to GABA and Glu-Cl ionic channels and other sites of action need to be considered. 


\subsubsection{Navigation and orientation}

Navigation is essential in enabling the honey bees to gather the food required for colony development. It may be considered as the integrative component of vision, olfaction, orientation and signal treatment (Zhang et al. 1999; Reinhard et al. 2004; Barron et al. 2005; Menzel et al. 2006; Pahl et al. 2011). The communication of food source location is a fundamental feature in navigation, particularly when the distances involved are greater than $100 \mathrm{~m}$. The impacts of pesticides on the communication of food source location have been studied in pioneer experiments (Schricker and Stephen 1970). Parathion prevents the bees from communicating the correct direction of a food source to other bees by inciting them to shift to a wrong angle during the waggle communication dance. The errors made by scout bees are minimal or absent when the bees do a waggle dance on a horizontal comb and are very marked on a vertical comb (Stephen and Schricker 1970). Foragers indicates reduced distances through an increase of waggle dance rhythm, with no difference on horizontal and vertical combs. This indicates that gravity does not greatly influence the analysis of distance by bees. Dances performed on a vertical comb in the dark results from the transposition of information from a horizontal to a vertical plane (Stephen and Schricker 1970). Thus, the alteration of waggle dance angle occurring only in a vertical plane suggests the existence of at least two independent neural systems for the treatment of azimuthal information, of which one is gravity-dependent. The errors made by the bees in indicating distances may result from different neural processes. The evaluation of distances by bees involves the integration of the optic flow during travel (Esch et al. 2001; Dacke and Srinivasan 2007). Thus, an alteration of optic signal treatment could lead to mis-estimated distances. Flight time seems to be a poor indicator of waggle dance behaviour because the neural mechanisms involved in the treatment of the optic signal is complex. On the one hand, evaluation of distances involves the integration of the optic flow, which is dependent on the flight speed, and on the other, flight speed is also regulated by optic flow (Srinivasan et al. 1996; Barron et al. 2005).

The homing or return flight is the flight performed by the bees from the food source to the hive. It represents an integrative tool in assessing adverse sublethal effects of pesticides. Deltamethrin interferes with homing behaviour and induces an exacerbated phototropism in the foragers (Vandame et al. 1995). It is difficult to determine whether deltamethrin also alters other functions, such as orientation or vision. Different technologies have been developed for investigating insect movements in different space scales and dimensions (Reynolds and Riley 2002). Two of the approaches seem very suitable for studying navigation and homing flight. The first uses harmonic radar to analyse movement in the landscape by bees fitted with a transponder and has the advantage of allowing for 3-D observation of free-flying bees (Riley et al. 1996, 2005). It has been used to reveal particular traits of orientation flight ontogeny, particularly constant trip duration associated with flight speed that increases with experience (Capaldi et al. 2000), and to demonstrate the use of map-like spatial memory in honey bee navigation (Menzel et al. 2005). The second approach is based on radiofrequency identification (RFID; Streit et al. 2003). Individuals are tagged with a passive RFID microchip that emits a specific individualised radio signal after activation by a radio frequency. RFID has been used to study the foraging behaviour and the circadian foraging rhythm of bumble bees (Ohashi et al. 2010; Stelzer et al. 2010). This approach has shown that phenylpyrazole fipronil elicits a decrease in the number of individual foraging flights and an increase in the time needed to achieve a homing flight (Decourtye et al. 2011). Concerning neonicotinoids, exposure to imidacloprid and clothianidin leads to a reduction of foraging activity and longer foraging flights (Schneider et al. 2012). Harmonic radar and RFID methodologies have complementary advantages. Harmonic radar can be used to manage space and time in behavioural 
studies, but its experimental device submits the bees to constraints, especially due to the presence of an antenna on the dorsal thorax. RFID microchips are less cumbersome, but their very short detection distance makes them more suitable for managing time than space.

\subsection{Behaviour}

Modifications of bee behaviour elicited by pesticides can be considered as a result of a combination of changes that occurs at neural and physiological levels. At the neural level, it seem obvious that neurotoxic insecticides may impair the correct functioning of neural cells, and especially neurons, with repercussions on physiological activities such as secretion, muscle activity, cognitive functions, respiration or digestion. However, the action of insecticides can be exerted through disturbance in neural programmes regulating the life of the bees, e.g. internal clock, distance evaluation and communication. At the physiological level, changes in behaviour may result from the incapacity of bees to achieve adequate metabolic homeostasis or to regulate efficiently metabolic pathways in response to environmental changes or to changes in physiological activity, as it has been shown for the honey bee and other species (Bounias et al. 1985; Gordon and Watkinson 1988; Tomasi et al. 2001; El Hassani et al. 2008, 2009; Ruzzin et al. 2009; Evrard et al. 2010; Mommaerts et al. 2010).

\subsubsection{Foraging}

Foraging controls the food resources of the honey bee colony and, thus, is closely related to the fate of the honey bee populations. Pesticides repellent or antifeedant to bees may alter foraging behaviour and, if the effects last too long, induce a starvation state or a nutritional deficiency both at the individual and colony levels. Pesticides may also act by disrupting neural functions, thus causing erroneous interpretation of external stimuli or incapacity to achieve neural programmes involved in behaviour or in response to external stimuli. This may lead to deficient food gathering as a result of alteration of olfactive functions or lack of motivation. Carbamate and OP insecticides share common molecular targets, cholinesterases and, particularly acetylcholinesterase, an enzyme involved in the control of cholinergic nerve transmission, but may elicit different effects. The repellent effect of carbamates seems less questionable than that of OP (Nigg et al. 1991). A field insecticidal treatment with OP fenitrothion elicits a dramatic decrease in the number of bees foraging on flowering pigeon pea plants for about 1 week (Pande and Bandopadhyay 1985). When the bees are exposed to acute treatments with OP, the effects observed are more complex (Guez et al. 2005). After a methyl-parathion treatment at a dose of $50 \mathrm{ng}$ bee $^{-1}$, the bees visited a feeder more frequently. A more complex effect is observed at the dose of $10 \mathrm{ng}$ bee $^{-1}$ and an initial decrease in frequency is followed by an increase. After a field treatment, a decrease in the frequency of visits to a food source could easily be explained by a repellent effect, as observed with pyrethroids, although there could have been other causes such as altered vitality and lack of motivation (Rieth and Levin 1988, 1989; Vaidya et al. 1996). Conversely, after an acute individual treatment, the differential effect of methyl-parathion on the foraging activity suggests a more complex mechanism of action. The differential action of methyl-parathion might be due to dose-dependent toxicokinetics that would result in different lengths of time required by the insecticide to reach the critical toxicological internal concentration at the target site (Guez et al. 2001, 2005). However, a dual effect, i.e. a decrease of foraging activity followed by an increase, supports the existence of molecular targets of different affinities for methylparathion. Furthermore, an increase in the visit frequency induced by methyl-parathion may be explained by enhanced attraction to the food, energetic stress or greater foraging activity due to a transient hyperactivation of the cholinergic transmission. This said, important discrepancies in the action of OP have been documented. Dimethoate does not appear as a repellent but 
exhibits a differential action with low tarsal contact toxicity and high oral toxicity (Barker et al. 1980; Danka and Collison 1987). In the field, dicrotophos, sprayed on white clover, induces a rapid arrest of foraging that lasts 4 days and a delayed mortality 7-8 days after the treatment (Clinch et al. 1973). Since OP are not repellent, their effects are consistent with a loss of bee vitality that induces an immediate and almost total decrease in foraging activity associated with a high delayed mortality rate (Waller et al. 1979; Shires et al. 1984a, b). This explains the results of tunnel experiments with colonies of about 10,000 individuals showing mortality rates of around 3,000 bees after a dimethoate treatment, although only about 300 bees had been exposed, and an absence of foraging activity during 3 days (unpublished data). Neonicotinoids, represented by imidacloprid, seem to present a less complex action. Effects observed with imidacloprid included a decrease in the frequency of visits to a feeding source, a lower proportion of active bees at the food source, an increase in intervals between visits, abnormalities in revisiting the feeding site and reduced visual learning capacities (Nielsen et al. 2000; Colin et al. 2004; Ramirez-Romero et al. 2005; Yang et al. 2008; Han et al. 2010). This clearly shows that the over-activation of the cholinergic system by an acetylcholinesterase inhibition, with OP, or an agonist action on $\mathrm{nAChR}$, with neonicotinoids, does not result in the same final effects. This strongly suggests that OP and neonicotinoids may interact with targets different from those of the cholinergic system.

\subsection{Physiological functions}

\subsubsection{Thermoregulation}

The honey bee is an insect that achieves thermoregulation to control its body temperature. Thermoregulation involves thermogenesis, by a tetanic contraction of flight muscles, and thermolysis, by wing beating and water evaporation, both at the individual and colony level. The control of body temperature allows the bees to fly at temperatures ranging from $11{ }^{\circ} \mathrm{C}$ to $46{ }^{\circ} \mathrm{C}$ and heat their swarms and their broods. It also plays a role in the transmission of information during the communication dance and in the rapidity of nectar processing (Heinrich 1980a, b; Southwick 1982, 1983, 1987; Southwick and Heldmaier 1987; Fahrenholz et al. 1989; Farina and Wainselboim 2001; Stabentheiner 2001, 2003; Kleinhenz et al. 2003).

Pyrethroid insecticides and azole fungicides (imidazoles and triazoles) may act synergistically to induce lethal potentiations, which may occur at very low field rates of deltamethrin (less than $0.5 \mathrm{~g} / \mathrm{ha}$ ) and are subject to seasonal variation (Colin and Belzunces 1992; Meled et al. 1998). Azole fungicides are both inducers and inhibitors of cytochromes P-450 enzymes involved in the metabolism of xenobiotics (Riviere 1983; Bach and Snegaroff 1989; Laignelet et al. 1989; Antignac et al. 1990; Kapteyn et al. 1994; Pilling et al. 1995; Johnston et al. 1996; Babin et al. 2005). This initially suggested an action of azole fungicides on pyrethroid metabolism. However, the extreme rapidity of the synergistic effect of pyrethroid-azole associations suggests an action at the neural level (Chalvet-Monfray et al. 1995, 1996a, b; Pilling et al. 1995; Vandame et al. 1995). Pyrethroids exhibit a negative temperature coefficient below $28-30{ }^{\circ} \mathrm{C}$ and induce a higher toxicity at low temperatures than at high temperatures (Wang et al. 1972; Punzo 1993). This negative temperature coefficient, and the temperature range in which it is observed, is compatible with a neural action of pyrethroids on thermogenesis. To explore this action, honey bees were exposed to sublethal doses of deltamethrin corresponding to field rates 16 to 150 times lower than the registered dosage (7.5 $\mathrm{g} \mathrm{ha}^{-1}$ ). At these doses, deltamethrin triggers a drastic hypothermia that lasts for more than $4 \mathrm{~h}$ (Vandame and Belzunces 1998). Surprisingly, deltamethrin and prochloraz, at doses eliciting no effect on body temperature, may act by potentiation when associated and induce a strong hypothermia. Whether the joint action of deltamethrin and prochloraz on thermoregulation is due to an inhibition of the activating aminergic pathway involved in thermogenesis or to an 
activation of the inhibiting pathway needs further research (Belzunces et al. 1996). However, similar thermogenesis impairment has also been observed with organophosphates, pesticides inhibiting acetylcholinesterase (Schmaranzer et al. 1987). This strongly supports the involvement of a cholinergic pathway in the negative control of thermogenesis that could be activated by pyrethroids. Action through thoracic ganglia, which play a major role in thermogenesis, should be considered (Kammer 1968; Hanegan 1973; Heinrich 1974; Murphy and Heath 1983) but the deltamethrin doses able to induce hypothermia can affect the homing flight without altering flight activity (Vandame et al. 1995). This rules out the possibility of hypothermia due to muscular incoordination or impairment of muscle contraction and strongly suggests a parallel action at the brain level. Hence, bees would be capable of coordinated flight muscle contraction but would not be able to execute the neural programme to achieve tetanic shivering (Linn and Roelofs 1984). The pyrethroid-induced hypothermia may have a strong impact in the spring when bees are subjected to low temperatures requiring an efficient thermogenesis.

\subsubsection{Muscle activity}

In all organisms, muscular contraction is involved in almost all physiological functions and plays an essential role in activities such as communication, motion, digestion and heart beating. The effects of pesticides on the muscle activity of insects, particularly honey bees, have seldom been investigated. In the house fly Musca domestica, pyrethroids such as transtetramethrin, trans-barthrin and kadethrin disrupt tight coupling between right and left flight muscles (Adams and Miller 1980). This prevents the achievement of a coordinated flight and renders the individual more vulnerable to its environment. In the honey bee, attention has first been focused on a pyrethroid insecticide, deltamethrin, and an imidazole fungicide, prochloraz, two active substances that, when associated, induce synergy and potentiation (Colin and Belzunces 1992; Pilling and Jepson
1993; Vandame and Belzunces 1998). In a study using semi-isolated heart, prochloraz and deltamethrin rapidly decrease the frequency and the force of the cardiac contractions with marked effects at $0.01 \mu \mathrm{M}$, equivalent to internal doses of 4-5 $\mu \mathrm{g} \mathrm{kg}^{-1}$ body weight (Papaefthimiou and Theophilidis 2001). In this study, prochloraz appears more cardiotoxic than deltamethrin. This is somewhat surprising since deltamethrin is a neurotoxic substance whereas prochloraz is an inhibitor and an inducer of cytochromes P450 enzymes, which are involved in the detoxication of xenobiotics and the metabolism of endogenous substances like steroids. An association of prochloraz and deltamethrin elicits a synergistic response that completely and rapidly abolishes heart contractions, thus confirming the neural basis of the deltamethrinprochloraz lethal and thermogenic synergy. Bee heart beating is not affected only by insecticides since the phenoxyacetic herbicide 2,4-D induces similar effects (Papaefthimiou et al. 2002). Conversely, triazine herbicides contribute to easier neurotransmitter release that results in an increase of the frequency and the force of cardiac contractions (Papaefthimiou et al. 2003). Concerning the synergistic effect of deltamethrin and prochloraz on heart activity, this is probably not due to an inhibition of deltamethrin metabolism by prochloraz, as was suggested for the lethal synergy, because deltamethrin biotransformation is negligible in semi-isolated heart (Colin and Belzunces 1992; Pilling et al. 1995). Initially, the insecticide activity of pyrethroids was ascribed to an action on voltagedependent sodium channels (Sattelle and Yamamoto 1988; Soderlund and Bloomquist 1989; Soderlund et al. 2002). Azole fungicides, such as triazoles and imidazoles, inhibit fungus ergosterol biosynthesis by preventing the cytochrome P-450-dependent $14 \alpha$-demethylation of lanosterol, and the cytochrome P-450-dependent metabolism of both endogenous and exogenous compounds (Snegaroff and Bach 1989). In fact, azole fungicides and pyrethroid insecticides may produce a joint action by interacting with shared molecular targets, such as ATPases and potassium and calcium channels, that are particularly 
important in muscle and nerve activity (Kabeer et al. 1987; Sattelle and Yamamoto 1988; Olivari et al. 1991; Aussel and Breittmayer 1993; Mason et al. 1993; Calore et al. 2000; Horváth et al. 2002; Lax et al. 2002; Soderlund et al. 2002; Kikuchi et al. 2005; Li et al. 2006a, b, c; Clark and Symington 2007; Abbadie et al. 2010; Neal et al. 2010; Han et al. 2011). Similar and complementary interactions with shared targets could also explain the rapid action and the lethal, thermogenic and cardiac synergies of pyrethroid-azole associations in bees. However, two interesting features emerge from the effects of pyrethroids on ATPases and exemplify the complex action of pyrethroid on the neural activity. First, the inhibition of $\mathrm{Ca}^{2+}$ $\mathrm{Mg}^{2+}$-ATPase by deltamethrin, and $\mathrm{N}^{+}-\mathrm{K}^{+}$ATPase by bifenthrin displays a negative temperature coefficient, as was observed for pyrethroid-induced toxicity ( $\mathrm{Li}$ et al. 2006a). Second, the metabolic synergist piperonyl butoxide (PBO), used to potentiate the field effects of pyrethroids by inhibiting their metabolism, not only inhibits ATPases but also potentiates the ATPase-inhibiting effects of pyrethroids (Kakko et al. 2000; Grosman and Diel 2005). This indicates that the role of ATPases in pyrethroid toxicity and azolepyrethroid and PBO-pyrethroid synergies is very likely underestimated.

\section{CONCLUSION AND PERSPECTIVES}

Insecticides can induce more or less serious effects on neural functions that can lead to an impairment of behaviour and physiological functions. The mechanisms by which insecticides elicit their effects are not restricted to the exclusive interaction between the active substance and the molecular target responsible for the insecticidal action. The effects of a given insecticide involve multiple molecular targets of different affinities for the molecule that can be recruited at different exposure levels and that may induce various effects, some of which are opposite or can induce a feedback action. Time appears as an important factor in insecticide toxicity. The final action of the insecticides is strongly dependent on the circadian rhythms, the time following exposure, the age or the developmental stage of the bees and the season. The route and the mode of exposure (acute, subchronic or chronic) play a particularly determining role in the nature and the intensity of the effects induced, and are often involved in differential effects elicited by a given substance. Metabolic processes modulate the intrinsic toxicity and may lead to metabolites that exhibit toxicity levels higher or lower than that of the parent compound and may elicit completely different effects. However, the simultaneous presence of several pesticides in a site or in food leads to interactions between substances that can drastically change the nature and the importance of the effects observed with one insecticide alone. Thus, investigations on pesticide combinations should take a more prevalent place in honey bee toxicology in the future. Because of the large number of pesticides, combinations to be studied will need to be prioritised. This could be based on the spatio-temporal occurrence of active substances.

The potential means to decrease the side effects of pesticides in the beneficial organisms, particularly the honey bees and pollinators, are of great concern. Different approaches involving highly repellent pesticides or genetic selection of pesticide-resistant bees have been proposed in the past. However, they were not considered fully satisfactory because of the unwanted impacts they can have on honey bees. Repellent substances with a long life span may elicit a drastic decrease in nectar and pollen gathering that could be damaging for both the honey bee colony and the beekeepers, and may prevent the proper pollination of crops. However, recent studies suggest that the combination of repellent and insecticide molecules can act synergistically on the insect pest (Pennetier et al. 2009). This type of action could be used advantageously to decrease the field dosages of pesticides, but it needs further investigation to assess the risk to the bees. The development of pesticide-resistant bees raises questions on food 
safety and genetic stability of colonies. It could be argued that pesticide-resistant bees could exhibit a higher survival rate after poisoning that enables them to harvest larger quantities of contaminated pollen or nectar. This could have harmful consequences for the human consumers of honey and pollen, and for honey bee colonies if the brood and the juveniles are more sensitive to pesticides than adult workers. Up to now, no pesticide-resistant bee populations have been reported. This is mainly due to the absence of strong selection pressure because the queen bee is not directly exposed to pesticides. Considering the variety and the complexity of the modes of action of the pesticides, it would not be possible to select bees that exhibit a multiple resistance due to biological targets that are less sensitive to pesticides. Multiple resistance based on an enhanced detoxification capacity should be more relevant but could create problems with pesticides having toxic metabolites such as organophosphates and neonicotinoids. However, in all cases of resistance, the problem of stabilising the resistant bee populations cannot be solved if the origin of queens and males in the apiary is not strictly controlled. A promising approach to preventing side effects of pesticides on beneficial organism has been derived from improved knowledge of the mode of action of pesticides in targeted pests and honey bees. Information on the mode of action can be used to develop substances that act selectively on pests. New substances might be designed to act preferentially on target subtypes of pests sensitive to insecticides such as neonicotinoids of phenylpyrazoles (Courjaret et al. 2003; Dupuis et al. 2010; Lavialle-Defaix et al. 2011; Bordereau-Dubois et al. 2012). A littleexplored way to act more selectively on pests consists in the designing of substances than act synergistically on the signalling pathways involved in the action of insecticides (Courjaret and Lapied 2001; Brandon et al. 2002; Es-Salah et al. 2008; Grünewald and Wersing 2008). This could improve the targeting of pesticides on pests and help to reduce the field dosages for decreasing the environmental impacts and the hazard to honey bees.

\section{ACKNOWLEDGEMENTS}

The authors thank Pr Bruno Lapied for his critical reading of the manuscript

Effets des insecticides sur le système nerveux de l'abeille

insecticides / effets sur le système nerveux / mode d'action / cibles moléculaires / comportement / cognition / Apidae

\section{Neuronale Wirkungen von Insektiziden in der Honigbiene}

insektizide / neuronale wirkungen / wirkmechanismen / zielmoleküle / verhalten / Apidae

\section{REFERENCES}

Abbadie, C., McManus, O.B., Sun, S.-Y., Bugianesi, R.M., Dai, G., Haedo, R.J., Herrington, J.B., Kaczorowski, G.J., Smith, M.M., Swensen, A.M., Warren, V.A., Williams, B., Arneric, S.P., Eduljee, C., Snutch, T.P., Tringham, E.W., Jochnowitz, N., Liang, A., MacIntyre, D.E., McGowan, E., Mistry, S., White, V.V., Hoyt, S.B., London, C., Lyons, K.A., Bunting, P.B., Volksdorf, S., Duffy, J.L. (2010) Analgesic effects of a substituted N-triazole oxindole (TROX-1). A state-dependent, voltagegated calcium channel 2 blocker. J. Pharmacol. Exp. Ther. 334, 545-555

Adams, M.E., Miller, T.A. (1980) Neural and behavioral correlates of pyrethroid and DDT-type poisoning in the house fly, Musca domestica L. Pestic. Biochem. Physiol. 13, 137-147

Adigun, A.A., Wrench, N., Seidler, F.J., Slotkin, T.A. (2010) Neonatal Organophosphorus pesticide exposure alters the developmental trajectory of cellsignaling cascades controlling metabolism: differential effects of diazinon and parathion. Environ. Health Perspect. 118, 210-215

Aliouane, Y., El Hassani, A.K., Gary, V., Armengaud, C., Lambin, M., Gauthier, M. (2009) Subchronic exposure of honeybees to sublethal doses of pesticides: Effects on behavior. Environ. Toxicol. Chem. 28, 113-122

Antignac, E., Koch, B., Grolier, P., Cassand, P., Narbonne, J.F. (1990) Prochloraz as potent inhibitor of benzo-[A]pyrene metabolism and mutagenic activity in rat-liver fractions. Toxicol. Lett. 54, 309-315

Armengaud, C., Causse, N., Aït-Oubah, J., Ginolhac, A., Gauthier, M. (2000) Functional cytochrome oxidase histochemistry in the honeybee brain. Brain Res. 859, 390-393 
Atkins, E.L., Macdonald, R.L., McGovern, T.P., Beroza, M., Greywood-Hale, E.A. (1975) Repellent additives to reduce pesticide hazards to honeybees: laboratory testing. J. Apic. Res. 14, 85-97

Atkins, E.L., Kellum, D., Neuman, K.J. (1977) Repellent additives to reduce pesticide hazards to honey bees. Am. Bee J. 117, 438-457

Aussel, C., Breittmayer, J.P. (1993) Imidazole antimycotics inhibitors of cytochrome P450 increase phosphatidylserine synthesis similarly to $\mathrm{K}^{+}$-channel blockers in Jurkat T cells. FEBS Lett. 319, 155-158

Babin, M., Casado, S., Chana, A., Herradon, B., Segner, H., Tarazona, J.V., Navas, J.M. (2005) Cytochrome $\mathrm{P} 4501 \mathrm{~A}$ induction caused by the imidazole derivative Prochloraz in a rainbow trout cell line. Toxicol. in Vitro 19, 899-902

Bach, J., Snegaroff, J. (1989) Effects of the fungicide prochloraz on xenobiotic metabolism in rainbowtrout-In-vivo induction. Xenobiotica 19, 1-9

Balderrama, N., Nunez, J., Giurfa, M., Torrealba, J., DeAlbornoz, E.G., Almeida, L.O. (1996) A deterrent response in honeybee (Apis mellifera) foragers: Dependence on disturbance and season. J. Insect Physiol. 42, 463-470

Barbara, G., Grünewald, B., Paute, S., Gauthier, M., Raymond-Delpech, V. (2008) Study of nicotinic acetylcholine receptors on cultured antennal lobe neurones from adult honeybee brains. Invert. Neurosci. 8, 19-29

Barker, R.J., Lehner, Y., Kunzmann, M.R. (1980) Pesticides and honey bees-Nectar and pollen contamination in Alfalfa treated with dimethoate. Arch. Environ. Contam. Toxicol. 9, 125-133

Barron, A.B., Zhu, H., Robinson, G.E., Srinivasan, M.V. (2005) Influence of flight time and flight environment on distance communication by dancing honey bees. Insectes Sociaux 52, 402-407

Barton, K.A., Whiteley, H.R., Yang, N.S. (1987) Bacillus thuringiensis delta-endotoxin expressed in transgenic Nicotiana tabacum provides resistance to Lepidopteran insects. Plant Physiol. 85, 1103-1109

Belzunces, L.P., Vandame, R., Gu, X.F. (1996) Modulation of honey bee thermoregulation by adrenergic compounds. Neuroreport 7, 1601-1604

Benzidane, Y., Touinsi, S., Motte, E., Jadas-Hécart, A., Communal, P.-Y., Leduc, L., Thany, S.H. (2010) Effect of thiamethoxam on cockroach locomotor activity is associated with its metabolite clothianidin. Pest Manag. Sci. 66, 1351-1359

Bernadou, A., Démares, F., Couret-Fauvel, T., Sandoz, J.C., Gauthier, M. (2009) Effect of fipronil on sidespecific antennal tactile learning in the honeybee. J. Insect Physiol. 55, 1099-1106

Bitterman, M.E., Menzel, R., Fietz, A., Schafer, S. (1983) Classical conditioning of proboscis extension in honeybees (Apis mellifera). J. Comp. Psychol. 97, 107-119

Bloch, G. (2010) The Social Clock of the Honeybee. J. Biol. Rhythms 25, 307-317
Bordereau-Dubois, B., List, O., Calas-List, D., Marques, O., Communal, P.-Y., Thany, S.H., Lapied, B. (2012) Transmembrane potential polarization, calcium influx and receptor conformational state modulate the sensitivity of the imidacloprid-insensitive neuronal insect nAChR to the neonicotinoid insecticides. J. Pharmacol. Exp. Ther. doi:10.1124/jpet.111.188060

Bos, C., Masson, C. (1983) Repellent effect of deltamethrin on honey bees. Agronomie 3, 545-553

Bounias, M., Dujin, N., Popeskovic, D.S. (1985) Sublethal effects of a synthetic pyrethroid, deltamethrin, on the glycemia, the lipemia, and the gut alkaline phosphatases of honeybees. Pestic. Biochem. Physiol. 24, 149-160

Brandon, N.J., Jovanovic, J.N., Smart, T.G., Moss, S.J. (2002) Receptor for activated C kinase-1 facilitates protein kinase $\mathrm{C}$-dependent phosphorylation and functional modulation of $\mathrm{GABA}(\mathrm{A})$ receptors with the activation of G-protein-coupled receptors. J. Neurosci. 22, 6353-6361

Braun, G., Bicker, G. (1992) Habituation of an appetitive reflex in the honeybee. J. Neurophysiol. 67, 588598

Brunet, J.L., Badiou, A., Belzunces, L.P. (2005) In vivo metabolic fate of $\left[{ }^{14} \mathrm{C}\right]$-acetamiprid in six biological compartments of the honeybee, Apis mellifera L. Pest Manag. Sci. 61, 742-748

Caboni, P., Sammelson, R.E., Casida, J.E. (2003) Phenylpyrazole insecticide photochemistry, metabolism, and GABAergic action: Ethiprole compared with fipronil. J. Agric. Food Chem. 51, 7055-7061

Calore, E.E., Cavaliere, M.J., Puga, F.R., Calore, N.M.P., Rosa, A.Rd., Weg, R., Dias, Sd.S., Santos, R.Pd. (2000) Histologic Peripheral Nerve Changes in Rats Induced by Deltamethrin. Ecotoxicol. Environ. Saf. 47, 82-86

Cano Lozano, V., Gauthier, M. (1998) Effects of the Muscarinic Antagonists Atropine and Pirenzepine on Olfactory Conditioning in the Honeybee. Pharmacol. Biochem. Behav. 59, 903-907

Cano Lozano, V., Bonnard, E., Gauthier, M., Richard, D. (1996) Mecamylamine-induced impairment of acquisition and retrieval of olfactory conditioning in the honeybee. Behav. Brain Res. 81, 215-222

Cano Lozano, V., Armengaud, C., Gauthier, M. (2001) Memory impairment induced by cholinergic antagonists injected into the mushroom bodies of the honeybee. J. Comp. Physiol. A 187, 249-254

Capaldi, E.A., Smith, A.D., Osborne, J.L., Fahrbach, S.E., Farris, S.M., Reynolds, D.R., Edwards, A.S., Martin, A., Robinson, G.E., Poppy, G.M., Riley, J.R. (2000) Ontogeny of orientation flight in the honeybee revealed by harmonic radar. Nature 403, 537-540

Chalvet-Monfray, K., Belzunces, L.P., Colin, M.E., Fleche, C., Sabatier, P. (1995) Modelling synergistic effects of two toxic agents in the honeybee. J. Biol. Syst. 3, 253-263

Chalvet-Monfray, K., Auger, P., Belzunces, L.P., Fleche, C., Sabatier, P. (1996a) Modelling based method for 
pharmacokinetic hypotheses test. Acta Biotheoretica 44, 335-348

Chalvet-Monfray, K., Belzunces, L.P., Colin, M.E., Fleche, C., Sabatier, P. (1996b) Synergy between deltamethrin and prochloraz in bees: Modeling approach. Environ. Toxicol. Chem. 15, 525-534

Chambers, J.E. (1992) The role of target site activation of phosphorothionates in acute Toxicity. In: Chambers, J.E., Levi, P.E. (eds.) Organophosphates: Chemistry, Fate and effects, pp. 229-239. Academic, San Diego

Clark, J., Symington, S. (2007) Pyrethroid action on calcium channels: neurotoxicological implications. Invert. Neurosci. 7, 3-16

Clinch, P.G., Palmer-Jones, T., Forster, I.W., Jones, T.P. (1973) Effect on honey bees of dicrotophos and methomyl applied as sprays to white clover. New Zealand J. Exp. Agric. 1, 97-99

Colin, M.E., Belzunces, L.P. (1992) Evidence of synergy between prochloraz and deltamethrin in Apis mellifera $\mathrm{L}-\mathrm{A}$ convenient biological approach. Pestic. Sci. 36, 115-119

Colin, M.E., Bonmatin, J.M., Moineau, I., Gaimon, C., Brun, S., Vermandere, J.P. (2004) A method to quantify and analyze the foraging activity of honey bees: Relevance to the sublethal effects induced by systemic insecticides. Arch. Environ. Contam. Toxicol. 47, 387-395

Colliot, F., Kukorowski, K.A., Hawkins, D.W., Roberts, D.A. (1992) Fipronil: a new soil and foliar broad spectrum insecticide. Proc., Brighton Crop Protect. Conf., Pests and Diseases, 1992 Brighton, November 23-26, 1992., 29-34

Courjaret, R., Lapied, B. (2001) Complex intracellular messenger pathways regulate one type of neuronal alpha-bungarotoxin-resistant nicotinic acetylcholine receptors expressed in insect neurosecretory cells (dorsal unpaired median neurons). Mol. Pharmacol. 60, 80-91

Courjaret, R., Grolleau, F., Lapied, B. (2003) Two distinct calcium-sensitive and -insensitive PKC upand down-regulate an alpha-bungarotoxin-resistant nAChR1 in insect neurosecretory cells (DUM neurons). Eur. J. Neurosci. 17, 2023-2034

Couvillon, M.J., Barton, S.N., Cohen, J.A., Fabricius, O.K., Kaercher, M.H., Cooper, L.S., Silk, M.J., Helantera, H., Ratnieks, F.L.W. (2010) Alarm pheromones do not mediate rapid shifts in honey bee guard acceptance threshold. J. Chem. Ecol. 36, 1306-1308

Dacke, M., Srinivasan, M.V. (2007) Honeybee navigation: distance estimation in the third dimension. J. Exp. Biol. 210, 845-853

Danka, R.G., Collison, C.H. (1987) Laboratory evaluation of dimethoate repellence to honey bees. J. Appl. Entomol. 104, 211-214

Decourtye, A., Lacassie, E., Pham-Delegue, M.H. (2003) Learning performances of honeybees (Apis mellifera
L) are differentially affected by imidacloprid according to the season. Pest Manag. Sci. 59, 269-278

Decourtye, A., Armengaud, C., Renou, M., Devillers, J., Cluzeau, S., Gauthier, M., Pham-Delègue, M.-H. (2004a) Imidacloprid impairs memory and brain metabolism in the honeybee (Apis mellifera L.). Pestic. Biochem. Physiol. 78, 83-92

Decourtye, A., Devillers, J., Cluzeau, S., Charreton, M., Pham-Delègue, M.-H. (2004b) Effects of imidacloprid and deltamethrin on associative learning in honeybees under semi-field and laboratory conditions. Ecotoxicol. Environ. Saf. 57, 410-419

Decourtye, A., Devillers, J., Genecque, E., Le Menach, K., Budzinski, H., Cluzeau, S., Pham-Delegue, M.H. (2005) Comparative sublethal toxicity of nine pesticides on olfactory learning performances of the honeybee Apis mellifera. Arch. Environ. Contam. Toxicol. 48, 242-250

Decourtye, A., Devillers, J., Aupinel, P., Brun, F., Bagnis, C., Fourrier, J., Gauthier, M. (2011) Honeybee tracking with microchips: a new methodology to measure the effects of pesticides. Ecotoxicology 20, 429-437

Déglise, P., Grünewald, B., Gauthier, M. (2002) The insecticide imidacloprid is a partial agonist of the nicotinic receptor of honeybee Kenyon cells. Neurosci. Lett. 321, 13-16

Delabie, J., Bos, C., Fonta, C., Masson, C. (1985) Toxic and repellent effects of cypermethrin on the honeybee-Laboratory, glasshouse and field experiments. Pestic. Sci. 16, 409-415

Detzel, A., Wink, M. (1993) Attraction, deterrence or intoxication of bees (Apis mellifera) by plant allelochemicals. Chemoecology 4, 8-18

Dupuis, J.P., Bazelot, M., Barbara, G.S., Paute, S., Gauthier, M., Raymond-Delpech, V. (2010) Homomeric RDL and heteromeric RDL/LCCH3 GABA receptors in the honeybee antennal lobes: Two candidates for inhibitory transmission in olfactory processing. J. Neurophysiol. 103, 458-468

Dupuis, J.P., Gauthier, M., Raymond-Delpech, V. (2011) Expression patterns of nicotinic subunits alpha 2, alpha 7, alpha 8, and beta 1 affect the kinetics and pharmacology of ACh-induced currents in adult bee olfactory neuropiles. J. Neurophysiol. 106, 16041613

El Hassani, A.K., Dacher, M., Gauthier, M., Armengaud, C. (2005) Effects of sublethal doses of fipronil on the behavior of the honeybee (Apis mellifera). Pharmacol. Biochem. Behav. 82, 30-39

El Hassani, A.K., Dacher, M., Gary, V., Lambin, M., Gauthier, M., Armengaud, C. (2008) Effects of sublethal doses of acetamiprid and thiamethoxam on the behavior of the honeybee (Apis mellifera). Arch. Environ. Contam. Toxicol. 54, 653-661

El Hassani, A.K., Dupuis, J.P., Gauthier, M., Armengaud, C. (2009) Glutamatergic and GABAergic effects of fipronil on olfactory learning and memory in the honeybee. Invert. Neurosci. 9, 91-100 
Elbert, A., Overbeck, H., Iwaya, K., Tsuboi, S., (1990) Imidacloprid, a novel systemic nitromethylene analogue insecticide for crop protection. Brighton Crop Protection Conference, Pests and Diseases-1990. 1, 21-28

Enan, E., Matsumura, F. (1992) Specific-inhibition of calcineurin by type-II synthetic pyrethroid insecticides. Biochem. Pharmacol. 43, 1777-1784

Epstein, L.H., Robinson, J.L., Roemmich, J.N., Marusewski, A. (2011) Slow rates of habituation predict greater zBMI gains over 12 months in lean children. Eating Behav. 12, 214-218

Esch, H.E., Zhang, S.W., Srinivasan, M.V., Tautz, J. (2001) Honeybee dances communicate distances measured by optic flow. Nature 411, 581-583

Esquivel-Senties, M.S., Barrera, I., Ortega, A., Vega, L. (2010) Organophosphorous pesticide metabolite (DEDTP) induces changes in the activation status of human lymphocytes by modulating the interleukin 2 receptor signal transduction pathway. Toxicol. Appl. Pharmacol. 248, 122-133

Es-Salah, Z., Lapied, B., Le Goff, G., Hamon, A. (2008) RNA editing regulates insect gamma-aminobutyric acid receptor function and insecticide sensitivity. Neuroreport 19, 939-943

Evrard, E., Marchand, J., Theron, M., Pichavant-Rafini, K., Durand, G., Quiniou, L., Laroche, J. (2010) Impacts of mixtures of herbicides on molecular and physiological responses of the European flounder Platichthys flesus. Comp. Biochem. Physiol. C 152, 321-331

Fahrenholz, L., Lamprecht, I., Schricker, B. (1989) Thermal investigations of a honey bee colony: thermoregulation of the hive during summer and winter and heat production of members of different bee castes. J. Comp. Physiol. B 159, 551-560

Faiz, M.S., Mughal, S., Memon, A.Q. (2011) Acute and Late Complications of Organophosphate Poisoning. J. College Phys. Surg. Pakistan 21, 288-290

Farina, W.M., Wainselboim, A.J. (2001) Changes in the thoracic temperature of honeybees while receiving nectar from foragers collecting at different reward rates. J. Exp. Biol. 204, 1653-1658

Ford, K.A., Casida, J.E. (2006) Unique and Common Metabolites of Thiamethoxam, Clothianidin, and Dinotefuran in Mice. Chem. Res. Toxicol. 19, 1549-1556

Fukuto, T.R. (1990) Mechanism of action of organophosphorus and carbamate insecticides. Environ. Health Perspect. 87, 245-254

Gallai, N., Salles, J.-M., Settele, J., Vaissiere, B.E. (2009) Economic valuation of the vulnerability of world agriculture confronted with pollinator decline. Ecol. Econ. 68, 810-821

Galloway, T., Handy, R. (2003) Immunotoxicity of organophosphorous pesticides. Ecotoxicology 12, 345-363

Gauthier, M. (2010) State of the art on insect nicotinic acetylcholine receptor function in learning and memory. In: Thany, S.H. (ed.) Insect Nicotinic Acetylcholine Receptors, pp. 97-115. Springer, Berlin

Gauthier, M., Cano Lozano, V., Zaoujal, A., Richard, D. (1994) Effects of intracranial injections of scopolamine on olfactory conditioning retrieval in the honeybee. Behav. Brain Res. 63, 145-149

Gauthier, M., Dacher, M., Thany, S.H., Niggebrügge, C., Déglise, P., Kljucevic, P., Armengaud, C., Grünewald, B. (2006) Involvement of [alpha]-bungarotoxin-sensitive nicotinic receptors in long-term memory formation in the honeybee (Apis mellifera). Neurobiol. Learn. Mem. 86, 164-174

Gawleta, N., Zimmermann, Y., Eltz, T. (2005) Repellent foraging scent recognition across bee families. Apidologie 36, 325-330

Giurfa, M. (1993) The repellent scent-mark of the honeybee Apis mellifera ligustica and its role as communication cue during foraging. Insectes Soc. 40, 59-67

Glynn, P. (2005) Neuropathy target esterase and phospholipid deacylation. Biochim. Biophys. Acta -Mol. Cell Biol. Lipids 1736, 87-93

Goldberg, F., Grünewald, B., Rosenboom, H., Menzel, R. (1999) Nicotinic acetylcholine currents of cultured Kenyon cells from the mushroom bodies of the honey bee Apis mellifera. J. Physiol. 514, 759-768

Gordon, C.J., Watkinson, W.P. (1988) Behavioral and autonomic thermoregulation in the rat following chlordimeform administration. Neurotoxicol. Teratol. 10, 215-219

Goulson, D., Chapman, J.W., Hughes, W.O.H. (2001) Discrimination of unrewarding flowers by bees; Direct detection of rewards and use of repellent scent marks. J. Insect Behav. 14, 669-678

Grosman, N., Diel, F. (2005) Influence of pyrethroids and piperonyl butoxide on the $\mathrm{Ca}^{2+}$-ATPase activity of rat brain synaptosomes and leukocyte membranes. Int. Immunopharmacol. 5, 263-270

Grünewald, B., Wersing, A. (2008) An ionotropic GABA receptor in cultured mushroom body Kenyon cells of the honeybee and its modulation by intracellular calcium. J. Comp. Physiol. A 194, 329-340

Guez, D., Suchail, S., Gauthier, M., Maleszka, R., Belzunces, L.P. (2001) Contrasting effects of imidacloprid on habituation in 7- and 8-day-old honeybees (Apis mellifera). Neurobiol. Learn. Mem. 76, 183-191

Guez, D., Belzunces, L.P., Maleszka, R. (2003) Effects of imidacloprid metabolites on habituation in honeybees suggest the existence of two subtypes of nicotinic receptors differentially expressed during adult development. Pharmacol. Biochem. Behav. 75, 217-222

Guez, D., Zhang, S.W., Srinivasan, M.V. (2005) Methyl parathion modifies foraging behaviour in honeybees (Apis mellifera). Ecotoxicology 14, 431-437 
Guez, D., Zhu, H., Zhang, S.W., Srinivasan, M.V. (2010) Enhanced cholinergic transmission promotes recall in honeybees. J. Insect Physiol. 56, 1341-1348

Han, P., Niu, C.-Y., Lei, C.-L., Cui, J.-J., Desneux, N. (2010) Use of an innovative T-tube maze assay and the proboscis extension response assay to assess sublethal effects of GM products and pesticides on learning capacity of the honey bee Apis mellifera L. Ecotoxicology 19, 1612-1619

Han, S., Zhang, Y., Chen, Q., Duan, Y., Zheng, T., Hu, X., Zhang, Z., Zhang, L. (2011) Fluconazole inhibits hERG $\mathrm{K}^{+}$channel by direct block and disruption of protein trafficking. Eur. J. Pharmacol. 650, 138-144

Hanegan, J.L. (1973) Control of heart rate in Cecropia moths; Response to thermal stimulation. J. Exp. Biol. 59, 67-76

Heinrich, B. (1974) Thermoregulation in endothermic insects. Science 185, 747-756

Heinrich, B. (1980a) Mechanisms of body-temperature regulation in honeybees, Apis mellifera. 1. Regulation of head temperature. J. Exp. Biol. 85, 61-72

Heinrich, B. (1980b) Mechanisms of body-temperature regulation in honeybees, Apis mellifera. 2. Regulation of thoracic temperature at high air temperatures. J. Exp. Biol. 85, 73-87

Hofte, H., Whiteley, H.R. (1989) Insecticidal crystal proteins of Bacillus thuringiensis. Microbiol. Rev. 53, 242-255

Horváth, F., Erdei, L., Wodala, B., Homann, U., Thiel, G. (2002) $\mathrm{K}^{+}$outward rectifying channels as targets of phosphatase inhibitor deltamethrin in Vicia faba guard cells. J. Plant Physiol. 159, 10971103

Ikeda, T., Zhao, X., Salgado, V., Kono, Y., Yeh, J.Z., Narahashi, T. (2003) Fipronil block of glutamateactivated chloride currents in cockroach neurons. Toxicol. Sci. 72, 310-310

Ito, A., Sasaguri, Y., Kitada, S., Kusaka, Y., Kuwano, K., Masutomi, K., Mizuki, E., Akao, T., Ohba, M. (2004) A Bacillus thuringiensis crystal protein with selective cytocidal action to human cells. J. Biol. Chem. 279, 21282-21286

James, C. (2006) Global Status of Commercialized Biotech/GM Crops: 2006. ISAAA Brief ISAAA, Ithaca, NY

Jansens, S., Clercq, R.d., Reynaerts, A., Peferoen, M., De Clercq, R. (1992) Greenhouse evaluation of transgenic tomato plants, expressing a Bacillus thuringiensis insecticidal crystal protein, for control of Helicoverpa armigera (Lepidoptera: Noctuidae). Mededelingen van de Faculteit Landbouwwetenschappen, Universiteit Gent 57, 515-522

Johnston, A.M., Lohr, J., Moes, J., Solomon, K.R., Zaborski, E.R. (1986) Toxicity of synergized and unsynergized nitromethylene heterocycle insecticide (SD 35651) to susceptible and resistant strains of Musca domestica (Diptera, Muscidae). J. Econ. Entomol. 79, 1439-1442
Johnston, G., Dawson, A., Walker, C.H. (1996) Effects of prochloraz and malathion on the red-legged partridge: A semi-natural field study. Environ. Pollut. 91, 217-225

Jokanovic, M., Kosanovic, M., Brkic, D., Vukomanovic, P. (2011) Organophosphate induced delayed polyneuropathy in man: An overview. Clin. Neurol. Neurosurg. 113, 7-10

Joshi, S.C., Bansal, B., Jasuja, N.D. (2011) Evaluation of reproductive and developmental toxicity of cypermethrin in male albino rats. Toxicol. Environ. Chem. 93, 593-602

Kabeer, S., Ahammad, I., Rao, K.S.P., Desaiah, D. (1987) Pyrethroid inhibition of basal and calmodulin stimulated $\mathrm{Ca}^{2+}$-ATPase and adenylate cyclase in rat brain. J. Appl. Toxicol. 7, 75-80

Kadala, A., Charreton, M., Jakob, I., Le Conte, Y., Collet, C. (2011) A use-dependent sodium current modification induced by type I pyrethroid insecticides in honeybee antennal olfactory receptor neurons. NeuroToxicolology 32, 320-330

Kakko, I., Toimela, T., Tähti, H. (2000) Piperonyl butoxide potentiates the synaptosome ATPase inhibiting effect of pyrethrin. Chemosphere 40, 301-305

Kammer, A.E. (1968) Motor patterns during flight and warm-up in Lepidoptera. J. Exp. Biol. 48, 89-109

Kapteyn, J.C., Milling, R.J., Simpson, D.J., Dewaard, M.A. (1994) Inhibition of sterol biosynthesis in cellfree-extracts of Botrytis cinerea by prochloraz and prochloraz analogs. Pestic. Sci. 40, 313-319

Kather, R., Drijfhout, F.P., Martin, S.J. (2011) Task group differences in cuticular lipids in the honey bee Apis mellifera. J. Chem. Ecol. 37, 205-212

Kikuchi, K., Nagatomo, T., Abe, H., Kawakami, K., Duff, H.J., Makielski, J.C., January, C.T., Nakashima, Y. (2005) Blockade of HERG cardiac $\mathrm{K}^{+}$current by antifungal drug miconazole. British $\mathrm{J}$. Pharmacol. 144, 840-848

Kleinhenz, M., Bujok, B., Fuchs, S., Tautz, J. (2003) Hot bees in empty broodnest cells: heating from within. J. Exp. Biol. 206, 4217-4231

Klis, S.F.L., Nijman, N.J., Vijverberg, H.P.M., Vandenbercken, J. (1991a) Phenylpyrazoles, a new class of pesticide-Effects on neuromusculartransmission and acetylcholine responses. Pestic. Sci. 33, 213-222

Klis, S.F.L., Vijverberg, H.P.M., Vandenbercken, J. (1991b) Phenylpyrazoles, a new class of pesticides-An electrophysiological investigation into basic effects. Pestic. Biochem. Physiol. 39, 210-218

Kuwabara, M. (1957) Bildung des bedingten reflexes von Pavlovs typus bei der honigbiene, Apis mellifica. J. Fac Sci Hokkaido Uni. Ser. VI Zool. 13, 458-464

Laignelet, L., Narbonne, J.F., Lhuguenot, J.C., Riviere, J.L. (1989) Induction and inhibition of rat-liver cytochrome(s) P-450 by an imidazole fungicide (prochloraz). Toxicology 59, 271-284 
Lambin, M., Armengaud, C., Raymond, S., Gauthier, M. (2001) Imidacloprid-induced facilitation of the proboscis extension reflex habituation in the honeybee. Arch. Insect Biochem. Physiol. 48, 129-134

Laurent, F.M., Rathahao, E. (2003) Distribution of $\left[{ }^{14} \mathrm{C}\right]-$ imidacloprid in sunflowers (Helianthus annuus L.) following seed treatment. J. Agric. Food Chem 51, 8005-8010

Lavialle-Defaix, C., Apaire-Marchais, V., Legros, C., Pennetier, C., Mohamed, A., Licznar, P., Corbel, V., Lapied, B. (2011) Anopheles gambiae mosquito isolated neurons: A new biological model for optimizing insecticide/repellent efficacy. J. Neurosci. Meth. 200, 68-73

Lax, A., Soler, F., Fernandez-Belda, F. (2002) Inhibition of sarcoplasmic reticulum $\mathrm{Ca}^{2+}$-ATPase by miconazole. Am. J. of Physiol.-Cell Physiol. 283, C85C92

Leemans, J., Reynaerts, A., Hofte, H., Peferoen, M., Mellaert, H.v., Joos, H., Van Mellaert, H. (1990) Insecticidal crystal proteins from Bacillus thuringiensis and their use in transgenic crops. Alan R. Liss, New York

Li, P., Akk, G. (2008) The insecticide fipronil and its metabolite fipronil sulphone inhibit the rat $\alpha 1 \beta 2 \gamma 2 \mathrm{~L}$ GABAA receptor. British J. Pharmacol. 155, 783-794

Li, H., Feng, T., Liang, P., Shi, X., Gao, X., Jiang, H. (2006a) Effect of temperature on toxicity of pyrethroids and endosulfan, activity of mitochondrial $\mathrm{Na}^{+}$$\mathrm{K}^{+}$-ATPase and $\mathrm{Ca}^{2+}-\mathrm{Mg}^{2+}$-ATPase in Chilo suppressalis (Walker) (Lepidoptera: Pyralidae). Pestic. Biochem. Physiol. 86, 151-156

Li, H., Feng, T., Tao, L., Liu, X., Jiang, H., Lin, R., Liang, P., Gao, X., Li, H.P., Feng, T., Tao, L.M., Liu, X., Jiang, H., Lin, R.H., Liang, P., Gao, X.W. (2006b) Inhibition of ATPase activity in mitochondria of Chilo suppressalis by nine common insecticides. Acta Entomol. Sinica 49, 254-259

Li, J., Shao, Y., Ding, Z., Bao, H., Liu, Z., Han, Z., Millar, N.S. (2010a) Native subunit composition of two insect nicotinic receptor subtypes with differing affinities for the insecticide imidacloprid. Insect Biochem. Mol. Biol. 40, 17-22

Li, Y., Meissle, M., Romeis, J. (2010b) Use of maize pollen by adult Chrysoperla carnea (Neuroptera: Chrysopidae) and fate of Cry proteins in Bttransgenic varieties. J. Insect Physiol. 56, 157-164

Li, Z.-H., Zlabek, V., Grabic, R., Li, P., Machova, J., Velisek, J., Randak, T. (2010c) Effects of exposure to sublethal propiconazole on the antioxidant defense system and $\mathrm{Na}^{+}-\mathrm{K}^{+}$-ATPase activity in brain of rainbow trout, Oncorhynchus mykiss. Aquatic Toxicol. 98, 297-303

Lind, R.J., Clough, M.S., Reynolds, S.E., Earley, F.G.P. (1998) $\left[{ }^{3} \mathrm{H}\right]$-Imidacloprid Labels high- and lowaffinity nicotinic acetylcholine receptor-like binding sites in the Aphid Myzus persicae (Hemiptera: Aphididae). Pestic. Biochem. Physiol. 62, 3-14
Linn Jr., C.E., Roelofs, W.L. (1984) Sublethal effects of neuroactive compounds on pheromone response thresholds in male oriental fruit moths. Arch. Insect Biochem. Physiol. 1, 331-344

Maeder, V., Escher, B.I., Scheringer, M., Hungerbuhler, K. (2004) Toxic ratio as an indicator of the intrinsic toxicity in the assessment of persistent, bioaccumulative, and toxic chemicals. Environ. Sci. Technol. 38, 3659-3666

Maisonnasse, A., Lenoir, J.-C., Beslay, D., Crauser, D., Le Conte, Y. (2010) E-b-Ocimene, a volatile brood pheromone involved in social regulation in the honey bee colony (Apis mellifera). PLos One 5 (10): e13531

Mamood, A.N., Waller, G.D. (1990) Recovery of learning responses by honeybees following a sublethal exposure to permethrin. Physiol. Entomol. 15, 55-60

Mason, M.J., Mayer, B., Hymel, L.J. (1993) Inhibition of $\mathrm{Ca}^{2+}$ transport pathways in thymic lymphocytes by econazole, miconazole and SFK-96365. Am. J. Physiol. 264, C654-C662

Meled, M., Thrasyvoulou, A., Belzunces, L.P. (1998) Seasonal variations in susceptibility of Apis mellifera to the synergistic action of prochloraz and deltamethrin. Environ. Toxicol. Chem. 17, 25172520

Menzel, R., Erber, J., Masuhr, J. (1974) Learning and memory in the honeybee. In: Brown, B. (ed.) Experimental analysis of insect behaviour, pp. 195-217. Springer Verlag, Berlin

Menzel, R., Greggers, U., Smith, A., Berger, S., Brandt, R., Brunke, S., Bundrock, G., Hülse, S., Plümpe, T., Schaupp, F., Schüttler, E., Stach, S., Stindt, J., Stollhoff, N., Watzl, S. (2005) Honey bees navigate according to a map-like spatial memory. Proc. Nat. Acad. Sci. USA 102, 3040-3045

Menzel, R., De Marco, R.J., Greggers, U. (2006) Spatial memory, navigation and dance behaviour in Apis mellifera. J. Comp. Physiol. A 192, 889-903

Mommaerts, V., Reynders, S., Boulet, J., Besard, L., Sterk, G., Smagghe, G. (2010) Risk assessment for side-effects of neonicotinoids against bumblebees with and without impairing foraging behavior. Ecotoxicology 19, 207-215

Moore, D. (2001) Honey bee circadian clocks: behavioral control from individual workers to wholecolony rhythms. J. Insect Physiol. 47, 843-857

Murillo, L., Hamon, A., Es-Salah-Lamoureux, Z., Itier, V., Quinchard, S., Lapied, B. (2011) Inhibition of protein kinase $\mathrm{C}$ decreases sensitivity of GABA receptor subtype to fipronil insecticide in insect neurosecretory cells. NeuroToxicology 32, 828-835

Murphy Jr., B.F., Heath, J.E. (1983) Temperature sensitivity in the prothoracic ganglion of the cockroach, Periplaneta americana, and its relationship to thermoregulation. J. Exp. Biol. 105, 305-315 
Narahashi, T., Zhao, X., Ikeda, T., Salgado, V.L., Yeh, J.Z. (2010) Glutamate-activated chloride channels: Unique fipronil targets present in insects but not in mammals. Pestic. Biochem. Physiol. 97, 149-152

Nauen, R., Ebbinghaus-Kintscher, U., Schmuck, R. (2001) Toxicity and nicotinic acetylcholine receptor interaction of imidacloprid and its metabolites in Apis mellifera (Hymenoptera: Apidae). Pest Manag. Sci. 57, 577-586

Nauen, R., Ebbinghaus-Kintscher, U., Salgado, V.L., Kaussmann, M. (2003) Thiamethoxam is a neonicotinoid precursor converted to clothianidin in insects and plants. Pestic. Biochem. Physiol. 76, 55-69

Neal, A.P., Yuan, Y., Atchison, W.D. (2010) Allethrin Differentially Modulates Voltage-Gated Calcium Channel Subtypes in Rat PC12 Cells. Toxicol. Sci. 116, 604-613

Nielsen, S.A., Brodsgaard, C.J., Hansen, H. (2000) Effects on detoxification enzymes in different life stages of honey bees (Apis mellifera L., Hymenoptera: Apidae) treated with a synthetic pyrethroid (flumethrin). Atla-Altern. Labor. Anim. 28, 437-443

Nigg, H.N., Russ, R.V., Mahon, W.D., Stamper, J.H., Knapp, J.L. (1991) Contamination of sucrose solution with aldicarb sulfoxide inhibits foraging by honeybees (Hymenoptera, Apidae). J. Econ. Entomol. 84, 810-813

Ohashi, K., D'Souza, D., Thomson, J.D. (2010) An automated system for tracking and identifying individual nectar foragers at multiple feeders. Behav. Ecol. Sociobiol. 64, 891-897

Olivari, C., Pugliarello, M.C., Cocucci, M.C., Rasicaldogno, F. (1991) Effects of penconazole on plasma-membranes isolated from radish seedlings. Pestic. Biochem. Physiol. 41, 8-13

Pahl, M., Zhu, H., Tautz, J., Zhang, S. (2011) Large Scale Homing in Honeybees. PLos One 6, e19669

Pande, Y.D., Bandopadhyay, S. (1985) Effect of fenitrothion on the foraging activity of honey bees on Cajanus cajan in Tripura. Indian Bee J. 47, 42-43

Papaefthimiou, C., Theophilidis, G. (2001) The Cardiotoxic action of the pyrethroid insecticide deltamethrin, the azole fungicide prochloraz, and their synergy on the semi-isolated heart of the Bbee Apis mellifera macedonica. Pestic. Biochem. Physiol. 69, 77-91

Papaefthimiou, C., Pavlidou, V., Gregorc, A., Theophilidis, G. (2002) The action of 2,4-Dichlorophenoxyacetic acid on the isolated heart of insect and amphibia. Environ. Toxicol. Pharmacol. 11, 127-140

Papaefthimiou, C., Zafeiridou, G., Topoglidi, A., Chaleplis, G., Zografou, S., Theophilidis, G. (2003) Triazines facilitate neurotransmitter release of synaptic terminals located in hearts of frog (Rana ridibunda) and honeybee (Apis mellifera) and in the ventral nerve cord of a beetle (Tenebrio molitor). Comp. Biochem. Physiol. C 135, 315-330

Pennetier, C., Costantini, C., Corbel, V., Licciardi, S., Dabire, R.K., Lapied, B., Chandre, F., Hougard,
J.M. (2009) Synergy between repellents and organophosphates on bed nets: efficacy and behavioural response of natural free-flying An. gambiae mosquitoes. PLos One 4, e7896

Petroianu, G., Karcher, B., Kern, N., Bergler, W., Rufer, R. (2001) Paraoxon sensitive phenylvalerate hydrolase in assessing the severity of acute paraoxon poisoning. J. Toxicol. Clin. Toxicol. 39, 27-31

Pigott, C.R., Ellar, D.J. (2007) Role of receptors in Bacillus thuringiensis crystaltoxin activity. Microbiol. Mol. Biol. Rev. 71, 255-281

Pilling, E.D., Jepson, P.C. (1993) Synergism between EBI fungicides and a pyrethroid insecticide in the honeybee (Apis mellifera). Pestic. Sci. 39, 293-297

Pilling, E.D., Bromley-Challenor, K.A.C., Walker, C.H., Jepson, P.C. (1995) Mechanism of synergism between the pyrethroid insecticide lambda-cyhalothrin and the imidazole fungicide prochloraz, in the honeybee (Apis mellifera L). Pestic. Biochem. Physiol. 51, 111

Polyzou, A., Froment, M.T., Masson, P., Belzunces, L.P. (1998) Absence of a protective effect of the Oxime 2-PAM toward paraoxon-poisoned honey bees: Acetylcholinesterase reactivation not at fault. Toxicol. Appl. Pharmacol. 152, 184-192

Punzo, F. (1993) Detoxification enzymes and the effects of temperature on the toxicity of pyrethroids to the fall armyworm, Spodoptera frugiperda (Lepidoptera, Noctuidae). Comp. Biochem. Physiol. C 105, $155-158$

Ramirez-Romero, R., Chaufaux, J., Pham-Delegue, M.H. (2005) Effects of CrylAb protoxin, deltamethrin and imidacloprid on the foraging activity and the learning performances of the honeybee Apis mellifera, a comparative approach. Apidologie 36, 601-611

Ramirez-Romero, R., Desneux, N., Decourtye, A., Chaffiol, A., Pham-Delègue, M.H. (2008) Does $\mathrm{Cry} 1 \mathrm{Ab}$ protein affect learning performances of the honey bee Apis mellifera L. (Hymenoptera, Apidae)? Ecotoxicol. Environ. Saf. 70, 327-333

Reinhard, J., Srinivasan, M.V., Zhang, S.W. (2004) Scent-triggered navigation in honeybees. Nature 427, 411-411

Reynolds, D.R., Riley, J.R. (2002) Remote-sensing, telemetric and computer-based technologies for investigating insect movement: a survey of existing and potential techniques. Comput. Elect. Agric. 35, 271-307

Rieth, J.P., Levin, M.D. (1988) The repellent effect of two pyrethroid insecticides on the honey bee. Physiol. Entomol. 13, 213-218

Rieth, J.P., Levin, M.D. (1989) Repellency of two phenylacetate-ester pyrethroids to the honeybee. J. Apic. Res. 28, 175-179

Riley, J.R., Smith, A.D., Reynolds, D.R., Edwards, A.S., Osborne, J.L., Williams, I.H., Carreck, N.L., Poppy, G.M. (1996) Tracking bees with harmonic radar. Nature 379, 29-30 
Riley, J.R., Greggers, U., Smith, A.D., Reynolds, D.R., Menzel, R. (2005) The flight paths of honeybees recruited by the waggle dance. Nature 435, 205-207

Riviere, J.L. (1983) Prochloraz, a potent inducer of the microsomal cytochrome-P-450 system. Pestic. Biochem. Physiol. 19, 44-52

Ruzo, L.O., Holmstead, R.L., Casida, J.E. (1977) Pyrethroid photochemistry-Decamethrin. J. Agric. Food Chem. 25, 1385-1394

Ruzo, L.O., Gaughan, L.C., Casida, J.E. (1980) Pyrethroid photochemistry-S-Bioallethrin. J. Agric. Food Chem. 28, 246-249

Ruzzin, J., Petersen, R., Meugnier, E., Madsen, L., Lock, E.-J., Lillefosse, H., Ma, T., Pesenti, S., Sonne, S.B., Marstrand, T.T., Malde, M.K., Du, Z.-Y., Chavey, C., Fajas, L., Lundebye, A.-K., Brand, C.L., Vidal, H., Kristiansen, K., Frøyland, L. (2009) Persistent Organic Pollutant Exposure Leads to Insulin Resistance Syndrome. Environ. Health Perspect. 118, 465-471

Sadler, N., Nieh, J.C. (2011) Honey bee forager thoracic temperature inside the nest is tuned to broad-scale differences in recruitment motivation. J. Exp. Biol. 214, 469-475

Sanahuja, G., Banakar, R., Twyman, R.M., Capell, T., Christou, P. (2011) Bacillus thuringiensis: a century of research, development and commercial applications. Plant Biotechnol. J. 9, 283-300

Sattelle, D.B., Yamamoto, D. (1988) Molecular targets of pyrethroid insecticides. Adv. Insect Physiol. 20, 147-213

Scharf, M.E., Siegfried, B.D. (1999) Toxicity and neurophysiological effects of fipronil and fipronil sulfone on the western corn rootworm (Coleoptera: Chrysomelidae). Arch. Insect Biochem. Physiol. 40, 150-156

Schmaranzer, S., Stabentheiner, A., Heran, H. (1987) Effect of Roxion-S (dimethoate) on the body temperature of the honey bee. In: Eder, J., Rembold, H. (eds.) Chemical Biology of Social Insects, p. 241. Verlag, München

Schneider, C.W., Tautz, J., Grünewald, B., Fuchs, S. (2012) RFID Tracking of Sublethal Effects of Two Neonicotinoid Insecticides on the Foraging Behavior of Apis mellifera. PLoS One 7, e30023

Schricker, B. (1974) Der einfluss subletaler dosen von parathion (E 605) auf das zeitgedächtnis der honigbiene. Apidologie 5, 385-398

Schricker, B., Stephen, W.P. (1970) The effect of sublethal doses of parathion on honeybee behaviour. I. Oral administration and the communication dance. J. Apic. Res. 9, 141-153

Schroeder, M.E., Flattum, R.F. (1984) The mode of action and neurotoxic properties of the nitromethylene heterocycle insecticides. Pestic. Biochem. Physiol. 22, 148-160

Seifert, J., Stollberg, J. (2005) Antagonism of a neonicotinoid insecticide imidacloprid at neuromus- cular receptors. Environ. Toxicol. Pharmacol. 20, $18-21$

Shires, S.W., Leblanc, J., Debray, P., Forbes, S., Louveaux, J. (1984a) Field experiments on the effects of a new pyrethroid insecticide WL-85871 on bees foraging artificial aphid honeydew on winter-wheat. Pestic. Sci. 15, 543-552

Shires, S.W., Murray, A., Debray, P., Leblanc, J. (1984b) The effects of a new pyrethroid insecticide WL85871 on foraging honey bees (Apis-mellifera L). Pestic. Sci. 15, 491-499

Sidiropoulou, E., Sachana, M., Flaskos, J., Harris, W., Hargreaves, A.J., Woldehiwet, Z. (2011) Fipronil interferes with the differentiation of mouse $\mathrm{N} 2 \mathrm{a}$ neuroblastoma cells. Toxicol. Lett. 201, 86-91

Snegaroff, J., Bach, J. (1989) Effects of the fungicide prochloraz on xenobiotic metabolism in rainbowtrout-Inhibition in-vitro and time course of induction in-vivo. Xenobiotica 19, 255-267

Soderlund, D.M., Bloomquist, J.R. (1989) Neurotoxic actions of pyrethroid insecticides. Annu. Rev. Entomol. 34, 77-96

Soderlund, D.M., Clark, J.M., Sheets, L.P., Mullin, L.S., Piccirillo, V.J., Sargent, D., Stevens, J.T., Weiner, M.L. (2002) Mechanisms of pyrethroid neurotoxicity: implications for cumulative risk assessment. Toxicology 171, 3-59

Solomon, M.G., Hooker, K.J.M. (1989) Chemical reppelents for reducing pesticide hazard to honeybees in apple orchards. J. Apic. Res. 28, 223-227

Southwick, E.E. (1982) Metabolic energy of intact honey bee colonies. Comp. Biochem. Physiol. A 71, 277281

Southwick, E.E. (1983) The honey bee cluster as a homeothermic superorganism. Comp. Biochem. Physiol. A 75, 641-645

Southwick, E.E. (1987) Cooperative metabolism in honey bees: An alternative to antifreeze and hibernation. J. Therm. Biol. 12, 155-158

Southwick, E.E., Heldmaier, G. (1987) Temperature control in honey bee colonies. Bioscience 37, 395-399

Srinivasan, M.V. (2011) Honeybees as a Model for the Study of Visually Guided Flight, Navigation, and Biologically Inspired Robotics. Physiol. Rev. 91, 413-460

Srinivasan, M.V., Zhang, S.W., Lehrer, M., Collett, T.S. (1996) Honeybee navigation en route to the goal: Visual flight control and odometry. J. Exp. Biol. 199, 237-244

Stabentheiner, A. (2001) Thermoregulation of dancing bees: thoracic temperature of pollen and nectar foragers in relation to profitability of foraging and colony need. J. Insect Physiol. 47, 385-392

Stabentheiner, A., Vollmann, J., Kovac, H., Crailsheim, K. (2003) Oxygen consumption and body temperature of active and resting honeybees. J. Insect Physiol. 49, 881-889 
Stelzer, R.J., Stanewsky, R., Chittka, L. (2010) Circadian foraging rhythms of bumblebees monitored by radio-frequency identification. J. Biol. Rhythms 25, 257-267

Stephen, W.P., Schricker, B. (1970) The effect of sublethal doses of parathion. II. Site of parathion activity, and signal integration. J. Apic. Res. 9, 155164

Streit, S., Bock, F., Pirk, C.W.W., Tautz, J. (2003) Automatic life-long monitoring of individual insect behaviour now possible. Zoology 106, 169-171

Suchail, S., Guez, D., Belzunces, L.P. (2001) Discrepancy between acute and chronic toxicity induced by imidacloprid and its metabolites in Apis mellifera. Environ. Toxicol. Chem. 20, 2482-2486

Suchail, S., De Sousa, G., Rahmani, R., Belzunces, L.P. (2004) In vivo distribution and metabolisation of $\left[{ }^{14} \mathrm{C}\right]$-imidacloprid in different compartments of Apis mellifera L. Pest Manag. Sci. 60:1056-1062

Takahashi, N., Mikami, N., Yamada, H., Miyamoto, J. (1985) Photodegradation of the pyrethroid insecticide fenpropathrin in water, on soil and on plant foliage. Pestic. Sci. 16, 119-131

Tank, J.L., Rosi-Marshall, E.J., Royer, T.V., Whiles, M.R., Griffiths, N.A., Frauendorf, T.C., Treering, D.J. (2010) Occurrence of maize detritus and a transgenic insecticidal protein (Cryl Ab) within the stream network of an agricultural landscape. Proc. Nat. Acad. Sci. USA 107, 17645-17650

Taylor, K.S., Waller, G.D., Crowder, L.A. (1987) Impairment of a classical conditioned response of the honey bee (Apis mellifera) by sublethal doses of synthetic pyrethroid insecticides. Apidologie 18, 243-252

Thany, S.H., Gauthier, M. (2005) Nicotine injected into the antennal lobes induces a rapid modulation of sucrose threshold and improves short-term memory in the honeybee Apis mellifera. Brain Res. 1039, 216-219

Thany, S.H., Lenaers, G., Crozatier, M., Armengaud, C., Gauthier, M. (2003) Identification and localization of the nicotinic acetylcholine receptor alpha3 mRNA in the brain of the honeybee, Apis mellifera. Insect Mol. Biol. 12, 255-262

Thompson, H., Wilkins, S. (2003) Assessment of the synergy and repellency of pyrethroid/fungicide mixtures. Bull. Insectol. 56, 131-134

Tian, Y.C., Qin, X.F., Xu, B.Y., Li, T.Y., Fang, R.X., Mang, K.Q., Li, W.G., Fu, W.J., Li, Y.P., Zhang, S.F. (1991) Insect resistance of transgenic tobacco plants expressing delta-endotoxin gene of Bacillus thuringiensis. Chin J. Biotechnol. 7, 1-13

Tomasi, T.E., Ashcraft, J., Britzke, E. (2001) Effects of fungicides on thyroid function, metabolism, and thermoregulation in cotton rats. Environ. Toxicol. Chem. 20, 1709-1715

Tomizawa, M., Casida, J.E. (2005) Neonicotinoid insecticide toxicology: Mechanisms of selective action, Annu. Rev. Pharmacol. Toxicol. 45, 247-268
Ueda, K., Gaughan, L.C., Casida, J.E. (1974) Photodecomposition of resmethrin and related pyrethroids. J. Agric. Food Chem. 22, 212-220

UIPP (2011) La nature, une richesse à cultiver. Rapport d'activité 2010/2011, 29 pp

Vaeck, M., Reynaerts, A., Hofte, H., Vanderbruggen, H., Jansens, S., Leemans, J. (1987) Insect resistance in transgenic plants expressing Bacillus thuringiensis toxin genes. Anais da Soc. Entomol. Brasil 16, 427435

Vaidya, D.N., Kumar, S., Mehta, P.K. (1996) Repellency of some insecticides to Apis mellifera $\mathrm{F}$. foragers on treated bloom of sarson, Brassica campestris L. var. brown sarson. Ann. Biology (Ludhiana) 12, 134-138

Vandame, R., Belzunces, L.P. (1998) Joint actions of deltamethrin and azole fungicides on honey bee thermoregulation. Neurosci. Lett. 251, 57-60

Vandame, R., Meled, M., Colin, M.-E., Belzunces, L.P. (1995) Alteration of the homing-flight in the honey bee Apis mellifera L. Exposed to sublethal dose of deltamethrin. Environ. Toxicol. Chem. 14, 855-860

Waller, G.D., Barker, R.J., Martin, J.H. (1979) Effects of dimethoate on honey bee foraging. Chemosphere $\mathbf{8}$, 461-463

Wang, C.M., Narahashi, T., Scuka, M. (1972) Mechanism of negative temperature coefficient of nerve blocking action of allethrin. J. Pharmacol. Exp. Ther. 182, 442-453

Wei, J.-Z., Hale, K., Carta, L., Platzer, E., Wong, C., Fang, S.-C., Aroian, R.V. (2003) Bacillus thuringiensis crystal proteins that target nematodes. Proc. Nat. Acad. Sci. USA 100, 2760-2765

Wolstenholme, A.J., Horoszok, L., Raymond, V., Sattelle, D.B. (2000) GLC-3: A novel fipronil and BIDN-sensitive, but picrotoxinin-insensitive, Lglutamate-gated chloride channel subunit from Caenorhabditis elegans. Eur. J. Neurosci. 12, 398-398

Wraight, C.L., Zangerl, A.R., Carroll, M.J., Berenbaum, M.R. (2000) Absence of toxicity of Bacillus thuringiensis pollen to black swallowtails under field conditions. Proc. Nat. Acad. Sci. USA 97, 7700-7703

Wüstenberg, D.G., Grünewald, B. (2004) Pharmacology of the neuronal nicotinic acetylcholine receptor of cultured Kenyon cells of the honeybee, Apis mellifera. J. Comp. Physiol. A 190, 807-821

Yang, E.C., Chuang, Y.C., Chen, Y.L., Chang, L.H. (2008) Abnormal foraging behavior induced by sublethal dosage of imidacloprid in the honey bee (Hymenoptera: Apidae). J. Econ. Entomol. 101, 1743-1748

Yousef, M.I. (2010) Vitamin E modulates reproductive toxicity of pyrethroid lambda-cyhalothrin in male rabbits. Food Chem. Toxicol. 48, 1152-1159

Zhang, S.W., Lehrer, M., Srinivasan, M.V. (1999) Honeybee memory: navigation by associative grouping and recall of visual stimuli. Neurobiol. Learn. Mem. 72, 180-201 
Zhang, H., Wang, H., Ji, Y.-L., Zhang, Y., Yu, T., Ning, H., Zhang, C., Zhao, X.-F., Wang, Q., Liu, P., Xu, D.-X. (2010a) Maternal fenvalerate exposure during pregnancy persistently impairs testicular development and spermatogenesis in male offspring. Food Chem. Toxicol. 48, 1160-1169

Zhang, H., Wang, H., Wang, Q., Zhao, X.-F., Liu, P., Ji, Y.-L., Ning, H., Yu, T., Zhang, C., Zhang, Y., Meng, X.-H., Xu, D.-X. (2010b) Pubertal and early adult exposure to fenvalerate disrupts steroidogenesis and spermatogenesis in mice at adulthood. J. Appl. Toxicol. 30, 369-377

Zhao, X., Salgado, V.L. (2010) The role of GABA and glutamate receptors in susceptibility and resistance to chloride channel blocker insecticides. Pestic. Biochem. Physiol. 97, 153-160

Zhao, X.L., Salgado, V.L., Yeh, J.Z., Narahashi, T. (2003) Differential actions of fipronil and dieldrin insecticides on GABA-gated chloride channels in cockroach neurons. J. Pharmacol. Exp. Ther. 306, 914-924

Zhao, X.L., Yeh, J.Z., Salgado, V.L., Narahashi, T. (2004) Fipronil is a potent open channel blocker of glutamate-activated chloride channels in cockroach neurons. J. Pharmacol. Exp. Ther. 310, 192-201

Zhao, X., Yeh, J.Z., Salgado, V.L., Narahashi, T. (2005) Sulfone metabolite of fipronil blocks $\gamma$ aminobutyric acid- and glutamate-activated chloride channels in mammalian and insect neurons. J. Pharmacol. Exp. Ther. 314, 363-373

Zhao, Q., Li, Y., Xiong, L., Wang, Q. (2010) Design, Synthesis and Insecticidal Activity of Novel Phenylpyrazoles Containing a 2,2,2-Trichloro-1alkoxyethyl Moiety. J. Agric. Food Chem. 58, 4992-4998

Zhao, X.-F., Wang, Q., Ji, Y.-L., Wang, H., Liu, P., Zhang, C., Zhang, Y., Xu, D.-X. (2011) Fenvalerate induces germ cell apoptosis in mouse testes through the Fas/FasL signaling pathway. Arch. Toxicol. 85, 1101-1108

Zhou, T., Zhou, W., Wang, Q., Dai, P.-L., Liu, F., Zhang, Y.-L., Sun, J.-H. (2011) Effects of pyrethroids on neuronal excitability of adult honeybees Apis mellifera. Pestic. Biochem. Physiol. 100, 35-40 